\title{
Genetic Affiliation of Pre-Hispanic and Contemporary Mayas through Maternal Linage
}

\author{
Mirna Isabel Ochoa-Lugo, ${ }^{1}$ María de Lourdes Muñoz, ${ }^{1,2 *}$ Gerardo Pérez-Ramírez, ${ }^{1}$ Kristine G. Beaty, ${ }^{2}$ \\ Mauro López-Armenta, ${ }^{3}$ Javiera Cervini-Silva, ${ }^{4,5}$ Miguel Moreno-Galeana, ${ }^{1}$ Adrián Martínez Meza, ${ }^{6}$ \\ Eduardo Ramos, ${ }^{6}$ Michael H. Crawford, ${ }^{2}$ and Arturo Romano-Pacheco ${ }^{6,7}$
}

\section{ABSTRACT}

Maya civilization developed in Mesoamerica and encompassed the Yucatan Peninsula, Guatemala, Belize, part of the Mexican states of Tabasco and Chiapas, and the western parts of Honduras and El Salvador. This civilization persisted approximately 3,000 years and was one of the most advanced of its time, possessing the only known full writing system at the time, as well as art, sophisticated architecture, and mathematical and astronomical systems. This civilization reached the apex of its power and influence during the Preclassic period, from 2000 BCE to 250 CE. Genetic variation in the pre-Hispanic Mayas from archaeological sites in the Mexican states of Yucatan, Chiapas, Quintana Roo, and Tabasco and their relationship with the contemporary communities in these regions have not been previously studied. Consequently, the principal aim of this study was to determine mitochondrial DNA (mtDNA) variation in the pre-Hispanic Maya population and to assess the relationship of these individuals with contemporary Mesoamerican Maya and populations from Asia, Beringia, and North, Central, and South America. Our results revealed interactions and gene flow between populations in the different archaeological sites assessed in this study. The mtDNA haplogroup frequency in the pre-Hispanic Maya population (60.53\%, $34.21 \%$, and $5.26 \%$ for haplogroups A, C, and D, respectively) was similar to that of most Mexican and Guatemalan Maya populations, with haplogroup A exhibiting the highest frequency. Haplogroup B most likely arrived independently and mixed with populations carrying haplogroups A and C based on its absence in the pre-Hispanic Mexican Maya populations and low frequencies in most Mexican and Guatemalan Maya populations, although this also may be due to drift. Maya and Ciboneys sharing haplotype $\mathrm{H} 10$ belonged to haplogroup $\mathrm{Cl}$ and haplotype $\mathrm{H} 4$ of haplogroup D, suggesting shared regional haplotypes. This may indicate a shared genetic ancestry, suggesting more regional interaction between populations in the circum-Caribbean region than previously demonstrated. Haplotype sharing between the pre-Hispanic Maya and the indigenous populations from Asia, the Aleutian Islands, and North,

${ }^{1}$ Department of Genetics and Molecular Biology, Centro de Investigación y de Estudios Avanzados del Instituto Politécnico Nacional, Mexico City, Mexico.

${ }^{2}$ Laboratory of Biological Anthropology, University of Kansas, Lawrence, Kansas.

${ }^{3}$ Laboratorio de Genética del Instituto de Ciencias Forenses del Tribunal Superior de Justicia del Distrito Federal, Mexico City, Mexico.

${ }^{4}$ Earth Sciences Division, Lawrence Berkeley National Laboratory, Berkeley, California.

${ }^{5}$ Universidad Autónoma Metropolitana Unidad Cuajimalpa, Mexico City, Mexico.

${ }^{6}$ Department of Physical Anthropology, Instituto Nacional de Antropología e Historia, Mexico City, Mexico.

${ }^{7}$ Universidad del Claustro de Sor Juana, Mexico City, Mexico.

*Correspondence to: María de Lourdes Muñoz, Department of Genetics and Molecular Biology, Centro de Investigación y de Estudios Avanzados del Instituto Politécnico Nacional, Av. Instituto Politécnico Nacional 2508, Col. San Pedro Zacatenco, 07360, Mexico City, Mexico.E-mail: lmunoz@cinvestav.mx.

KEY WORDS: PRE-HISPANIC POPULATIONS, ANCIENT DNA, MITOCHONDRIAL DNA, INDIGENOUS PEOPLE, MESOAMERICA, AMERICA, MIGRATION.

Human Biology, Spring 2016, v. 88, no. 2, pp. 136-167. Copyright @ 2017 Wayne State University Press, Detroit, Michigan 48201 
Central, and South America provides evidence for gene flow from the ancestral Amerindian population of the pre-Hispanic Maya to Central and South America.

$\mathrm{T}$ he Maya civilization was one of the bestknown classical civilizations of Mesoamerica, which developed into a society equipped with astronomy, mathematics, a calendar system, hieroglyphic writing, astrology, and agricultural innovations. The Maya are an indigenous people of Mexico and Central America, and descendants of the people who built the great cities are still residing on the same lands.

Historical documentation suggests that the ancestors of the Maya came to the Yucatan Peninsula through the Bering land bridge from North Asia. Eventually, these Maya immigrated south to Lake Petén, Guatemala, where they established a kingdom with their capital and sacred city of Flores Island in the lake (Muñoz et al. 2012b). The Yucatan Peninsula became the principal region of a new culture, called Toltec/Maya, which formed when Toltec migrated from the north and integrated with the Maya people.

\section{Cultivation of the Maya Civilization}

Human activity in Mexico during the huntergatherer culture was sustained through corn cultivation, basic pottery, and stone tools that date back to the Holocene epoch in 7200 BCE (Ranere et al. 2009). Furthermore, a phytolith analysis of sediments from San Andres, Tabasco, confirmed the diffusion of maize cultivation from the tropical Mexican Gulf Coast > 7,000 years ago ( $~ 5800$ BCE), followed by the rapid spread of the crop to South and North America by the ancestors of the Maya (Pohl et al. 2007; da Fonseca et al. 2015; Piperno et al. 2009; Grobman et al. 2012). This diffusion is further supported by evidence suggesting that the introduction of maize into the Southwest United States occurred before 2050 BCE (Merrill et al. 2009; Kemp et al. 2010; Kohler and Reese 2014).

\section{Olmec Influence on Maya}

The Olmec, considered the oldest culture in Mesoamerica, settled along the Gulf of Mexico and began building cities of stone and brick during the Preclassic period. While the nature of the relationship between the Olmec and the Maya is unknown, some archeologists have suggested that the Maya were their descendants and/or trading partners (Benson 1967). Indirect evidence of the relatedness of the Olmec and Maya supports the notion that the Olmec may have been the precursors of Maya, as suggested by Arnaiz-Villena et al. (2000) based on HLA allele frequency distributions.

Inomata et al. (2013) and Pringle (2013) have also documented the growth of the ceremonial space into a plaza-pyramid complex at Ceibal, Guatemala, that predates the buildings at other lowland Maya sites, as well as the major occupations at the Olmec center of La Venta. Those authors suggested that the development of lowland Maya civilization resulted not directly from the influence of the Olmec but from interactions with groups in the southwestern Maya lowlands, Chiapas, the Pacific Coast, and the southern Gulf Coast. There is evidence for a settlement at La Venta between 1400 and 1150 BCE that expanded between 1150 and 800 BCE and developed into a major temple-town complex (Rust and Sharer 1988).

\section{Maya Language}

Language and culture could also have played a pivotal role in Mesoamerica during the colonization of the American continent. Proto-Mayan is the common ancestor of all modern Mayan languages today and the Classic Maya languages documented in the hieroglyphic inscriptions (Law 2013). According to the classification scheme by Campbell and Kaufman (1985), Proto-Mayan was split in six main branches: K'iche'an, Mamean, Q'anjob'alan, Ch'olan-Tseltalan, Yukatekan, and Wastekan. The first division occurred circa 2200 BCE, when Wastekan moved northwest along the Gulf Coast of Mexico. Subsequently, each subgroup was spawned, and at present time the Maya language family includes approximately 31 languages spoken by more than 5 million people in Guatemala, Mexico, Belize, Honduras, and in diaspora communities in the United States and Canada (Law 2013). Three languages are now extinct: Chikomuseltek (Campbell and Kaufman 1985), Ch'olti' (Houston et al. 2000; Law 2013), and the language of Maya hieroglyphic inscriptions recorded from approximately 20,000 terse 
hieroglyphic inscriptions (Law 2013). Linguistic and maternal genetic diversity have not been correlated in native Mexicans (Sandoval et al. 2009).

\section{Background on Maya Genetics}

Several important factors that could influence the magnitude of genetic admixture in the Maya include gene flow between different locations, including genetic exchange with people who adopted maize, other domesticates, and ceramic use but without a sedentary lifestyle for many centuries (Inomata et al. 2015), as well as gene flow introduced by rival Maya groups. A recent study has suggested that those early migratory people contributed to the monumental constructions and public ceremonies in the lowland Maya site of Ceibal (Inomata et al. 2015). That study supports the idea that the development of sedentism was a complex process involving and facilitating social interactions among diverse groups. Furthermore, Ragsdale and Edgar (2015) also suggested that trade and political relationships affected the population structure among Postclassic Mexican populations.

Several authors have used biological indicators such as dental morphology to reconstruct patterns of affinity among ancient and modern human groups (Scherer 2007; Cucina et al. 2015; Aubry 2009; Ragsdale and Edgar 2015). The study of the population structure of Classic period (250 BCE to $900 \mathrm{CE}$ ) Maya through analysis of the odontometric variation of 827 skeletons from 12 archaeological sites in Mexico, Guatemala, Belize, and Honduras indicated that the isolation-bydistance model is not applicable to the population structure of Classic period Maya (Scherer 2007). Further studies examining dental morphology and ${ }^{87} \mathrm{Sr}:{ }^{86} \mathrm{Sr}$ ratios indicated intense population dynamics in the peninsula during the Maya Classic period. Cucina et al. (2015) concluded that the different natures of the dental and isotopic indicators were consistent with proposed trade routes in the peninsula.

\section{Background Mitochondrial DNA}

From an archaeological perspective, the primary indicator of contact and the sharing of ideas or culture between populations is the presence of foreign goods or architectural patterns in archaeological sites. From a biological point of view, population interactions can be inferred through the genetic makeup of the population, in which a high diversity in both haplogroups and haplotypes can show evidence of admixture, whereas homogeneity in mtDNA lineages shows evidence of drift (Cann et al. 1987; Wallace et al. 1999; Pakendorf and Stoneking 2005; Nesheva 2014).

mtDNA has been used to elucidate the maternal evolutionary history of anatomically modern humans through the reconstruction of prehistoric human dispersals (Forster et al. 1996; Goebel et al. 2008; Theyab et al. 2012; Melton et al. 2013; Mendisco et al. 2014) and to study human genetic predispositions to various diseases (Chen et al. 2015; Montiel-Sosa et al. 2013; Scheibye-Knudsen et al. 2013; Delgado-Sánchez et al. 2007). These studies are possible because mtDNA is transmitted as a nonrecombining unit through maternal lineages, provides an exceptional record of mutations over time (Ingman et al. 2000; Meyer et al. 1999; Tamura 2000), and is present in numerous copies in each cell, and because databases of entire human mtDNA sequences are readily available for comparison (Falk et al. 2015; Shokolenko and Alexeyev 2015).

Previous studies investigating mtDNA in contemporary Maya populations have suggested that native Mexican populations are more closely related genetically to North American populations (González-Martín et al. 2015) and that this genetic structure is related to geography rather than to language. Additionally, genetic differences have been identified between the populations from the northern and central regions of Mexico and Mesoamerica (Gorostiza et al. 2012). Furthermore, the heterogeneity of the Nahuas suggests that this group is composed of several genetically distinct cultural groups that were absorbed by the Aztecs (González-Martín et al. 2015) and later admixed with the Maya populations.

These phylogenetic studies using mtDNA data suggest a demographic scenario that is compatible with moderate local endogamy and isolation of the contemporary Maya, combined with episodes of gene exchange between ethnic groups, and that the recent adoption of an ethnic identity in the Guatemalan Maya stems from a cultural rather than a biological basis (Söchtig et al. 2015).

Occupations in South America may have resulted from a different process involving multiple 


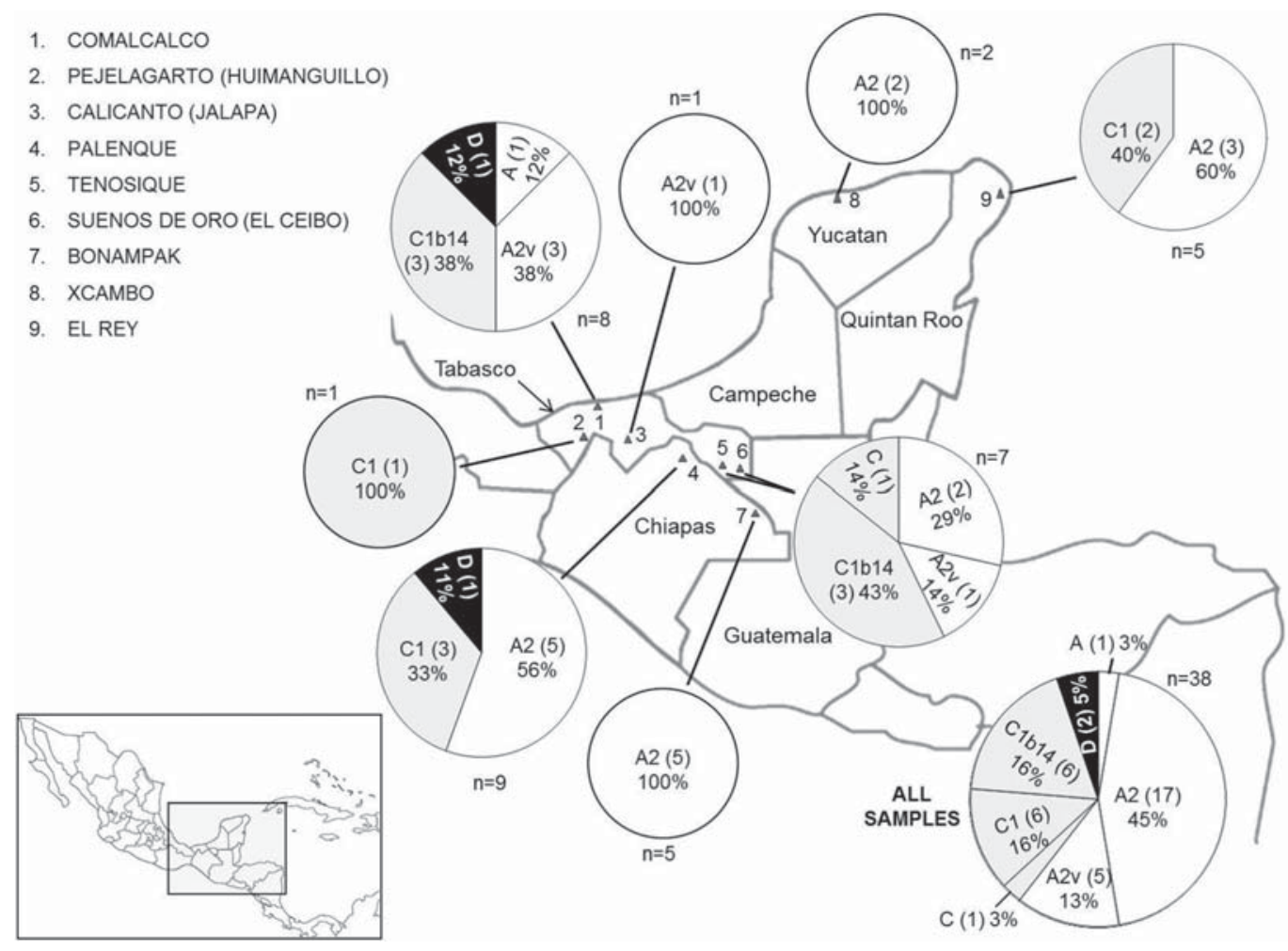

early migrations and subsequent population movements. Lewis et al. (2007) suggested that later regional isolation and differential evolutionary processes led to greater diversity estimated within western populations, and limited genetic differentiation estimated among western populations was likely attributed to larger population sizes and more extensive gene flow within this region, as well as a period of reduced population sizes and more restricted gene flow. Concurrently, the findings of de Saint Pierre (2012) indicated that the present native populations inhabiting South Chile and Argentina comprise a group with a common origin, suggesting a population break between the extreme south of South America and the more northern part of the continent. They concluded that the early colonization process was not just an expansion from north to south but also included movements across the Andes.

To date, no studies have investigated the origin and diversity of Maya maternal lineages in the Mexican region. This analysis addresses this deficiency through the use of pre-Hispanic samples from the archeological sites Xcambo, Bonampak (Group Frey and Group Quemado), Palenque (Temple XIII, Temple XV, Group B), El
Rey Quintana Roo, Comalcalco (Temple V, Temple III, Dren), Tenosique, Peje Lagarto Huimanguillo, Sueños de Oro, and Calicanto (Figure 1). In addition, genetic variation in these pre-Hispanic Mayas and their relationship with contemporary Maya populations (Yucatan, Guatemala, Honduras, and Belize), Asia, Beringia, North America, Central America and South America were determined to better understand their relationship and the effects of gene flow on contemporary Mayas (see Supplementary Figure S1).

\section{Materials and Methods}

\section{Archaeological Sites Contributing Bone Samples}

(1) Bonampak was occupied in the earliest Classic period (250 BCE) and is located in the Lacandon Jungle, $30 \mathrm{~km}$ to the south of Yaxchilan near the border of Mexico and Guatemala. Its maximal cultural peak at approximately $743 \mathrm{CE}$ is highlighted by one of the major features of this archaeological site: the mural paintings on buildings that surround the central plaza (Flores-Gutiérrez 2007). In this study we include four samples from Group Quemado located $250 \mathrm{~m}$ to the northeast of the Gran
FIGURE 1. Overview of the locations and origins of archaeological Maya sites in the Yucatan, Chiapas, and Tabasco where the pre-Hispanic samples collected. Each pie chart section shows the number and percentage of individuals possessing each haplogroup. The pie chart at the bottom right shows the percentages of each haplogroup in the 38 samples combined. 
Table 1. Features of Samples from the Pre-Hispanic Mayas (see also Figure 1)

\begin{tabular}{|c|c|c|c|c|c|c|}
\hline Archeological Site (Location, Latitude/Longitude) and Sample Code & Building & Burial (E) Tomb (T) & Age & Sex & Time Period (CE) & Haplotype \\
\hline \multicolumn{7}{|l|}{ Xcambo (Yucatan, $21.35^{\circ} /-89.266^{\circ}$ ) } \\
\hline MXYUCXCAMBO_E9b_A2 & Work areas & E9 & Adult & M & $250-550$ & A2 \\
\hline MXYUCXCAMBO_E14_A2 & Work areas & E14 & Adult & M & $250-550$ & A2 \\
\hline \multicolumn{7}{|l|}{ Bonampak (Chiapas, $16.704^{\circ} /-91.065^{\circ}$ ) } \\
\hline MXCHBONAMPAK_E1GF_A2 & Group Frey & E1 & Adult & M & $580-800$ & A2 \\
\hline MXCHBONAMPAK_E2GF_A2 & Group Frey & E2 & Adult & M & $580-800$ & A2 \\
\hline MXCHBONAMPAK_E3GF_A2 & Group Frey & E3 & Adult & M & $580-800$ & A2 \\
\hline MXCHBONAMPAK_E4GF_A2 & Group Frey & E4 & Adult & M & $580-800$ & A2 \\
\hline MXCHBONAMPAK_E3GQ_A2 & Group Quemado & E3 & Adult & M & $580-800$ & $\mathrm{~A} 2$ \\
\hline \multicolumn{7}{|l|}{ Palenque (Chiapas, $17.5092^{\circ} /-91.982^{\circ}$ ) } \\
\hline MXCHPALENQUE_T3PGTXV_A2 & $\mathrm{XV}$ & T3 & Adult & M & $750-800$ & A2 \\
\hline MXCHPALENQUE_E6ID TXV_D & $\mathrm{XV}$ & E6 IND-D & Adult & M & $750-800$ & $\mathrm{D}$ \\
\hline MXCHPALENQUE_TXIIIE3CHILD_A2 & XIII & E3 & Infant & M & $750-800$ & A2 \\
\hline MXCHPALENQUE_E2_A2 & XIII & E2 & Adult & $\mathrm{F}$ & $750-800$ & A2 \\
\hline MXCHPALENQUE_T5GB_A2 & Group B & T5 & Infant & M & $750-800$ & A2 \\
\hline MXCHPALENQUE_E2GB_A2 & Group B & $\mathrm{T} 2$ & Adult & $\mathrm{F}$ & $750-800$ & A2 \\
\hline MXCHPALENQUE_T4GB_C1 & Group B & T4 & Adult & $\mathrm{F}$ & $750-800$ & $\mathrm{Cl}$ \\
\hline MXCHPALENQUE_T1GB_C1 & Group B & $\mathrm{T} 1$ & Adult & $\mathrm{F}$ & $750-800$ & $\mathrm{C} 1$ \\
\hline MXCHPALENQUE_T3AGB_C1 & Group B & T3, IND-A & Adult & $\mathrm{F}$ & $750-800$ & $\mathrm{Cl}$ \\
\hline \multicolumn{7}{|l|}{ El Rey Quintana Roo (Quintana Roo, $21.061^{\circ} / 86.781^{\circ}$ ) } \\
\hline MXQRELREY_E23-1_A2 & & E23-1 & Adult & & $1200-1500$ & A2 \\
\hline MXQRELREY_E23-3_C1 & & E23-3 & Youth & & $1200-1500$ & $\mathrm{Cl}$ \\
\hline MXQRELREY_E8_A2 & & E8 & Adult & & $1200-1500$ & A2 \\
\hline MXRELREY_E9_C1 & & E9 & Adult & & $1200-1500$ & $\mathrm{C} 1$ \\
\hline MXQRRELREY_E27_A2 & & E27 & Adult & & $1200-1500$ & A2 \\
\hline \multicolumn{7}{|l|}{ Comalcalco (Tabasco, $18.280^{\circ} /-93.202^{\circ}$ ) } \\
\hline MXTABCOMALCALCO_T5EBCHILD_A2v & $\mathrm{v}$ & T5 & Infant & M & $700-900$ & $\mathrm{~A} 2 \mathrm{v}$ \\
\hline MXTABCOMALCALCO_T511_C1b14 & $\mathrm{V}$ & IND 1 & Adult & M & $700-900$ & $\mathrm{C} 1 \mathrm{~b} 14$ \\
\hline MXTABCOMALCALCO_T3E9_A2v & IIIA, North Plaza & E9 & Adult & M & $700-900$ & $A 2 v$ \\
\hline MXTABCOMALCALCO_T3E14_A & IIIA, North Plaza & E14 & Adult & M & $700-900$ & A \\
\hline MXTABCOMALCALCO_T3E7_A2v & IIIA, North Plaza & E7 & Adult & M & $700-900$ & $\mathrm{~A} 2 \mathrm{v}$ \\
\hline MXTABCOMALCALCO_T3AE6_C1b14 & IIIA, North Plaza & E6 & Adult & M & $700-900$ & $\mathrm{C} 1 \mathrm{~b} 14$ \\
\hline MXTABCOMALCALCO_P3AE2_D & IIIA, North Plaza & E2 & Adult & M & $700-900$ & D \\
\hline \multicolumn{7}{|l|}{ Dren, Comalcalco (Tabasco, $\left.18.280^{\circ} /-93.202^{\circ}\right)$} \\
\hline MXTABSITIODREN_E2_C1b14 & Work areas & E2 & Adult & M & $700-900$ & $\mathrm{C} 1 \mathrm{~b} 14$ \\
\hline \multicolumn{7}{|l|}{ Tenosique (Tabasco, $17.466^{\circ} /-91.416^{\circ}$ ) } \\
\hline MXTABTENOSIQUE_E2P8_A2 & Work areas & E2, Well 8 & Adult & M & $700-900$ & A2 \\
\hline MXTABTENOSIQUE_E6P6_A2 & Work areas & E6, Well 6 South & Adult & M & $700-900$ & $A 2 v$ \\
\hline MXTABTENOSIQUE_E7P65_A2v & Work areas & E7, Well 6 & Adult & M & $700-900$ & $A 2 v$ \\
\hline MXTABTENOSIQUE_E4P6CHILD_C1b14 & Work areas & E4, Well 6 & Infant & ND & $700-900$ & $\mathrm{C} 1 \mathrm{~b} 14$ \\
\hline MXTABTENOSIQUE_E3_C1b14 & Work areas & E3, Well 9 & Adult & M & $700-900$ & $\mathrm{C} 1 \mathrm{~b} 14$ \\
\hline \multicolumn{7}{|c|}{ Sueños de Oro (El Ciebo), Tenosique (Tabasco, 17.278889\%/-91.085833) } \\
\hline MXTABSUENOSDEORO_E1P1_C1b14 & Work areas & E1, Well 1 & Adult & M & $700-900$ & $\mathrm{C} 1 \mathrm{~b} 14$ \\
\hline MXTABSUENOSDEORO_E2P1_C & Work areas & E2, Well 1 & Adult & M & $700-900$ & $\mathrm{D}$ \\
\hline \multicolumn{7}{|l|}{ Calicanto, Jalapa (Tabasco, $17.732^{\circ} /-92.754^{\circ}$ ) } \\
\hline MXTABCALICANTO_E3VIP_A2v & Work areas & E3 & Main IND & M & $700-900$ & $\mathrm{~A} 2 \mathrm{v}$ \\
\hline Peje Lagarto Huimanguillo (Tabasco, $17.85^{\circ} /-93.383^{\circ}$ ) & Los Pinos & & & & & \\
\hline MXTABPEJELAGARTO_11_C1 & Pipe 1 & Individual 1 & Adult & M & $700-900$ & $\mathrm{C} 1$ \\
\hline
\end{tabular}

Abbreviations: ND, not determined; IND, individual. 
Plaza and one sample from Group Frey located 350 $\mathrm{m}$ to the north of the Acropolis (Figure 1, Table 1).

(2) The Classic Maya site of Palenque (226 BCE to $799 \mathrm{CE}$ ) is situated on a limestone shelf at the base of the Sierra de Palenque. Located near the Usumacinta River in the Mexican state of Chiapas, it lies approximately $130 \mathrm{~km}$ south of "Ciudad del Carmen" and $150 \mathrm{~m}$ above sea level. Remains from Palenque Temple XIII and Temple XV are distinguished by the naturalistic sculpture, architectural inventiveness, and detailed epigraphic record. At present, this region is inhabited by Chol-speaking Mayas (Schele 2012). The Mayas used old buildings to construct new temples, and an earlier structure lies beneath the Palace that was built before the construction of the galleries, suggesting a much earlier occupation of the site, probably by the same group of Mayas that constructed the rest of the ceremonial center (Ruz Lhuillier, cited in Schele 2012). This study includes nine samples from this archeological site (Figure 1, Table 1).

(3) Comalcalco ("House of Frying Pans" in Nahuatl) is one of the most significant ancient cities in Tabasco, and the only Mayan city built with bricks of baked clay instead of stone. This archaeological site is made up of three complexes: the North Square, the Great Acropolis and the Acropolis of the East. It is similar in design to Palenque, and it flourished as an agricultural center specializing in cacao. The clay bricks are decorated with iconography and/or hieroglyphs, sand and oyster shells. Comalcalco is believed to feature the earliest brick buildings found in Mesoamerica. The city was a center of the Chontal Maya people who flourished in $500 \mathrm{CE}$, and it was abandoned in approximately $1000 \mathrm{CE}$. The chemical composition of the figurines found in Comalcalco is equivalent to those found on Jaina Island (Ochoa 2004). Dren is also located in Comalcalco, but in the working areas. Thus, it is possible that the samples were from the common people living in this area. This study includes six samples from this archeological site (Figure 1, Table 1).

(4) Sueños de Oro; Tenosique; Calicanto, Jalapa; and Peje Lagarto, Huimanguillo, are small archaeological sites in Tabasco located proximal to the major archeological sites in Tabasco (Figure 1, Table 1). Sueños de Oro is also known as El Ceibo and is approximately $59 \mathrm{~km}$ from the municipality of Tenosique on the Guatemalan border. This study includes two samples from Sueños de Oro, five from Tenosique, one from Calicanto, and one from Peje Lagarto (Table 1).

(5) El Rey Quintana Roo, named Nizuctec (250-600 CE), is located in Cancun in the state of Quintana Roo-it was known as Nizuc in early Colonial times (Andrews 2006). This study includes five samples from this archaeological site (Figure 1, Table 1).

(6) Xcambo is a small archaeological site located $2 \mathrm{~km}$ from the northern coast of the Yucatan Peninsula in the municipality of Dzemul. The occupation of this city dates to 150 BCE to 300 CE. Archaeological evidence suggests that Xcambo provided salt to the Maya cities of Izamal, Oxkintok, and Ah Kim Pech (Aubry 2009). This study includes two samples from Xcambo (Figure 1, Table 1).

\section{Samples}

DNA analysis was performed for 38 pre-Hispanic individuals from the following archeological sites: Xcambo, Bonampak (Group Frey and Group Quemado), Palenque (Temple XIII, Temple XV, Group B), El Rey Quintana Roo, Comalcalco (Temple V, Temple III, Dren), Tenosique, Peje Lagarto Huimanguillo, Sueños de Oro, and Calicanto (Figure 1, Table 1). Archaeological bone samples $(0.5 \mathrm{mg})$ from two different areas of each skeleton were collected for this study. Pre-Hispanic bone samples were donated by the Instituto Nacional de Antropologia e Historia. One sample was eliminated because the DNA was damaged.

\section{Ancient Sample Preparation for DNA Extraction}

DNA purification was preceded by sample decontamination to eliminate exogenous surface DNA. Each sample was washed with full-strength Clorox bleach, followed by rinsing with DNA-free double-distilled $\mathrm{H}_{2} \mathrm{O}$ and ultraviolet irradiation of each facet for $30 \mathrm{~min}$ (Muñoz et al. 2012a). Gloves, masks, hats, coats, and filter pipette tips were used in all experiments to avoid sample contamination in the laboratory (Adler et al. 2011; Campos et al. 2012; Muñoz et al. 2012a).

All sample preparations, DNA extractions, and polymerase chain reaction (PCR) amplifications were completed in the ultraviolet sterilization room (positive-pressure clean room with filtered air), which contains an anteroom. The clean room 
is routinely cleaned with bleach, and all containers are wiped before being placed in the laboratory. A more complete explanation of the laboratory procedures and methods utilized in this analysis is provided in Smith et al. (2009). Furthermore, a database containing mitochondrial control region sequences is maintained for all personnel working in the laboratory and any personnel who may have come in contact with human remains prior to the DNA analysis.

\section{DNA Extraction}

Bone powder was generated by grinding the skeletal material with a mortar and pestle until a fine powder was obtained. The powder $(0.100 \mathrm{~g})$ was transferred into a sterile $15-\mathrm{ml}$ tube and suspended in $2 \mathrm{ml}$ extraction buffer $(0.01 \mathrm{M}$ Tris- $\mathrm{HCl}, 0.1 \mathrm{M}$ EDTA, and $0.2 \%$ SDS pH 8.0). The tubes were capped and sealed with Parafilm. After incubation with gentle agitation for $1 \mathrm{~h}$ at $37^{\circ} \mathrm{C}, 1 \mathrm{mg} / \mathrm{ml}$ proteinase $\mathrm{K}$ was added to the sample, followed by incubation at $50^{\circ} \mathrm{C}$ for $2 \mathrm{~h}$. Throughout the procedure, a blank extraction treated identically to the experimental samples was included to monitor potential contamination during the DNA extraction process. Finally, the samples were centrifuged at $5,000 \times g$ for $5 \mathrm{~min}$, and the supernatants were extracted using phenol:chloroform:isoamyl alcohol (24:24:1) for organic extraction (Hughes et al. 2006; Maniatis et al. 1989; Muñoz et al. 2012a). Subsequently, the aqueous phase was concentrated by precipitation via the addition of 0.1 volumes of $3 \mathrm{M}$ sodium acetate $\mathrm{pH} 5.0$ and 2.5 volumes of ethanol. After mixing, the sample was incubated at $-78^{\circ} \mathrm{C}$ overnight and centrifuged at $15,000 \mathrm{rpm}$ for 10 min at $4^{\circ} \mathrm{C}$. The supernatant was decanted, and the precipitate was rinsed with $70 \%$ ethanol. After drying the pellet at ambient temperature in a sterile area, the pellet was suspended in $100 \mu \mathrm{l}$ DNA-free sterile water. If ancient DNA was contaminated with inhibitors of polymerase DNase, the DNA was purified using the QIAquick Gel Extraction Kit (Qiagen, Valencia, CA) as recommended by the manufacturer. Alternatively, purification of ancient genomic DNA was also performed using magnetic bead technology (PerkinElmer, Baesweiler, Germany) in combination with chemagic Prepito-D (PerkinElmer), following the instructions of the supplier. Extracted DNA was maintained in aliquots of $10 \mu \mathrm{l}$ at $-70^{\circ} \mathrm{C}$.
Contamination controls lacking sample were also used in every DNA extraction and PCR to detect contamination. Additionally, a series of negative controls were routinely assessed using the protocol described by Malhi et al. (2010) and Muñoz et al. (2012a). The samples were extracted at least twice from each sample.

\section{PCR and DNA Sequencing}

The mtDNA hypervariable segment I (HVS-I) of the ancient DNA samples was amplified, sequenced (corresponding to nucleotide pairs 15989-16236, 16159-16236, and 16190-16410), and genotyped by real-time PCR (TaqMan) for the haplogroup diagnostic markers for mitochondrial haplogroups $\mathrm{A}$, C, D, and X (PE Applied Biosystems, Foster City, CA, USA). The primers used to amplify and sequence the HVS-I region of the ancient samples in this study were as follows:

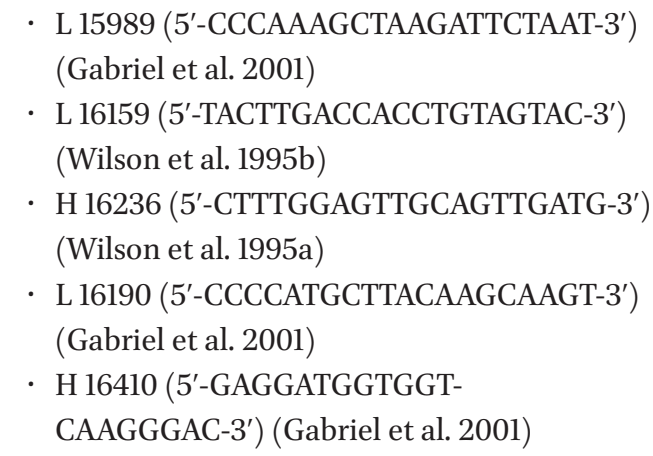

Nucleotide sequencing was carried out by direct sequencing with an ABI 3130xl Genetic Analyzer (Applied Biosystems). To provide additional confirmation that the ancient DNA results were not derived from laboratory-specific contaminants, the samples were also verified at the Insectary Laboratory and the Genetics Laboratory at the Institute of Forensic Sciences (Superior Court of Justice, Mexico City, Mexico).

If the replicate did not exhibit a sequence identical to the original, a third extraction, amplification, and sequence reaction was performed to resolve the ambiguity. Ancient DNA extraction and sequencing were replicated at the Insectary and the Institute of Forensic Sciences. Recently, ancient DNA extraction and sequencing have been replicated in two samples from La Cueva de San Felipe in Tabasco, Mexico, and in the ancient DNA laboratory of Dennis O'Rourke at the University of Utah in Salt Lake City. 


\section{Statistical Analysis}

Our analyses included a data set of 1,209 HVS-I mitochondrial sequences (38 from this study and 1,173 from published sources) from North, Central, and South America, as well as Beringia and SiberiaAsia (see Supplementary Table S1). The geographic location of each sample is presented in Supplementary Figure S1. These sequences were aligned and compared using the revised Cambridge Reference Sequence (rCRS) (Andrews et al. 1999) with BioEdit, version 7.2 .5 (update 12/11/2013; http:// www.mbio.ncsu.edu/bioedit/bioedit.html). The HVS-I region was examined between nucleotide positions 15989 and 16410 according to the rCRS modified version of the original CRS published by Anderson et al. (1981).

\section{Genetic Variability}

To quantify the genetic variability of the HVS-I mtDNA sequences in the Maya population, standard and molecular diversity indices were estimated: nucleotide diversity, mean number of pairwise differences $(\pi)$ (Tajima 1983; Nei 1987), expected diversity based on the number of pairwise differences $\left(\theta_{\pi}\right)$ (Tajima 1983), and the sequence diversity $(H)$ (Nei 1987). These diversity parameters were computed using Arlequin, version 3.5.2.1 (Excoffier and Lischer 2010).

All of the pre-Hispanic Maya samples collected in this study were pooled into eight groups based on the archeological site and the geographic criterion (Figure 1). In addition, three groups of sequences were included from different ancient populations (Ciboney from Cuba, Guane from Colombia, and a sample from the Archaeological Cemeteries of Chile). Following these same criteria, individual contemporary sequences were divided into six groups and named according to the geographic region: Asia; the Beringian bridge; North, Central, and South America; and contemporary Maya (see Supplementary Figure S1 and Table S1).

\section{Molecular Variance}

The genetic structure of the population among and within groups was estimated by analysis of molecular variance. To explore the demographic history of these pre-Hispanic populations, we analyzed the mismatch distribution as implemented in Arlequin, version 3.5.1.2 (Excoffier and Lischer 2010). Next, we measured Fu's $F s$ and Tajima's $D$ neutrality tests of the total number of segregating sites, also using Arlequin. A multidimensional scaling (MDS) plot based on pairwise distances was also constructed using R, version 3.1.2 (https://www.r-project.org/).

\section{Median Joining Network Analysis}

The genealogical relationships among the identified mtDNA control region haplotypes of the pre-Hispanic Maya populations from the archaeological sites were inferred by median joining network (Bandelt et al.1999) and calculated using Network, version 4.6.1.3 (http://www.fluxus-engineering. com/sharenet_rn.htm), accounting for different rates of transitions and transversions for all mutations and setting the parameter to zero to restrict the choices of feasible links in the final network. Neighbor joining tree clustering was constructed according to Kumar et al. (2011) using MEGA, version 6 (Tamura et al. 2013).

\section{Classification of mtDNA Haplogroups}

Finally, to classify the mtDNA haplotypes into haplogroups, we adopted the nomenclature system of Starikovskaya et al. (2005), Achilli et al. (2008), Derenko et al. (2010), Gómez-Carballa et al. (2015), Kumar et al. (2011), and Rieux et al. (2014). All detected polymorphic positions were confirmed with Mitomaster (http://www.mitomap.org/bin/ view.pl/MITOMASTER/WebHome). All new diagnostic positions indicated in these studies were taken into account by assigning the haplotypes to haplogroups/subhaplogroups. The haplogroup composition of the analyzed populations was then evaluated both on an Asian, Beringian Bridge, Amerindian scale and in the Maya context, to gain insights into the origin of the genetic differentiation of pre-Hispanic Mexican and contemporary Maya populations.

\section{Results and Discussion}

\section{mtDNA Diversity}

HVS-I of 38 Maya pre-Hispanic samples from different archeological sites in Mexico (Figure 1, Table 1) was sequenced to determine the haplogroup and relationship to maternal lineages of other geographic regions. All mtDNA haplotypes were in lineages A (2.6\%), A2 (44.73\%), A2v (13.16\%), C (2.6\%), Cl (15.8\%), Clbl4 (15.8\%), and D (5.3\%; 
Table 2). One sequence was classified in haplogroup A based on the presence of a $\mathrm{C}>\mathrm{T}$ transition at position 16223 and a $\mathrm{G}>\mathrm{A}$ transition at position 16319 (G16319A) (Torroni et al. 1993); 17 sequences were classified as haplogroup A2 base on the presence of $\mathrm{C}>\mathrm{T}$ transitions at positions 16111 (C16111T), 16223 (C16223T), and 16290 (C16290T), a G>A transition at position 16319 (G16319A), and a T $>C$ transition at position 16362 (T16362C) (Torroni et al. 1993; Starikovskaya et al.1998); and five sequences were classified as haplogroup A2v based on the presence of the transitions observed in haplogroup A2 and a $\mathrm{T}>\mathrm{C}$ transition at position 16239 (C16223T) (Kumar et al. 2011). No haplogroup B sequences were found in this pre-Hispanic group. One additional sequence was classified as haplogroup $\mathrm{C}$ based on the presence of a $\mathrm{T}>\mathrm{C}$ transition at position 16325 (T16325C); six were classified as haplogroup C1 based on the presence of haplogroup $\mathrm{C}$ and a $\mathrm{C}>\mathrm{T}$ transition at position 16327 (C16327T); and six sequences were classified as haplogroup Clb14 based on the presence of transitions detected in haplogroup $\mathrm{Cl}$ and a $\mathrm{G}>\mathrm{A}$ transition at position 16181 (G16181A) (Gómez-Carballa et al. 2015; Kumar et al. 2011; Rieux et al. 2014). Finally, two sequences corresponded to haplogroup D based on the absence of polymorphisms diagnostic of other haplogroups and of the transitions $\mathrm{C}>\mathrm{T}(\mathrm{Cl} 16223 \mathrm{~T})$ and $\mathrm{T}>\mathrm{C}(\mathrm{T} 16362 \mathrm{C})$, as proposed by Torroni et al. (1993) to classify HVS-I haplogroups.

\section{Distribution and Network Analysis of mtDNA Haplogroups}

mtDNA haplogroup frequency in the pre-Hispanic populations was analyzed to study Maya history and population dynamics. The haplogroup frequencies (Figure 1) show the geographic distribution in each pre-Hispanic population according to the archaeological site. We also calculated the frequency distribution of pairwise differences between sequences of mtDNA for pre-Hispanic and contemporary populations to evaluate rapid population expansion. The distribution of the pairwise differences for the four haplogroups was unimodal, with main peaks at 1 for haplogroup $A$ and at 2 for haplogroups B, C, and D, indicative of population expansion (Figure 2). Supplementary Figure S2, $A$ and $B$, shows the detailed mtDNA phylogenetic tree of pre-Hispanic Maya haplogroups and their immediate Siberian-Asian sister clades.

\section{Network Analysis of Haplogroup A}

Median joining networks of haplogroup A mtDNA HVS-I sequences were analyzed to determine the pattern of substitutions in the noncoding control HVS-I region. This analysis included sequences from nucleotides 16106-16399 (Figure 3) in this study (pre-Hispanic Maya populations) and from the GenBank database for Maya; North, Central, and South America; Beringia; and Asia (see Supplementary Table S1 and Figure S1). All samples/citations used for the network analysis are included in Supplementary Table S1. The results of this analysis revealed a total of 211 haplotypes in all individuals and 10 of 23 from the archaeological sites Xcambo, Bonampak (Group Frey and Group Quemado), Palenque (Temple XIII, Temple XV, and Group B), El Rey Quintana Roo, Comalcalco (Temple V, Temple III, and Dren), Tenosique, Peje Lagarto Huimanguillo, Sueños de Oro, and Calicanto (Table 2, Figure 3). These haplotypes were subdivided into subclusters, depending on the presence or absence of the characteristics of the HVS-I variants (Figure 3).

This analysis revealed one main diversification center, lineage H3, encompassing pre-Hispanic sequences from Xcambo (E9b), El Rey Quintana Roo (E23-1), Bonampak (E1GF, E2GF, E3GF, E4GF, E3GQ), and Palenque (T3PGTXV) and contemporary individuals from northern Asia, Siberia, Aleutian Islands, Canada, and Central and South America and contemporary native Mexicans, Maya from Mexico and Guatemala, and Chibchan from Nicaragua and Costa Rica (Figure 3, Table 3). In addition, the pre-Hispanic sequences from Xcambo (E14b), Palenque (E2GB, XIII_E3), and Comalcalco T3E9 and sequences from contemporary individuals from Colombia (Chibchan) and Peru (Quechua) were grouped in this haplotype in a second analysis using sequences from nucleotides 16213-16399 (see Supplementary Figure S3 and Table S1). Figure 4 and Table 3 display the geographic distribution of this haplotype and shared haplotypes, respectively. The result is indicative of a common ancestor of the populations from North Asia that migrated through the Bering Strait bridge, through Canada and the United States, down through Mexico and the Maya region, and from there to Central and South America.

Haplotype H30 was shared by two pre-Hispanic individuals from Comalcalco (T3E9) and Tenosique 


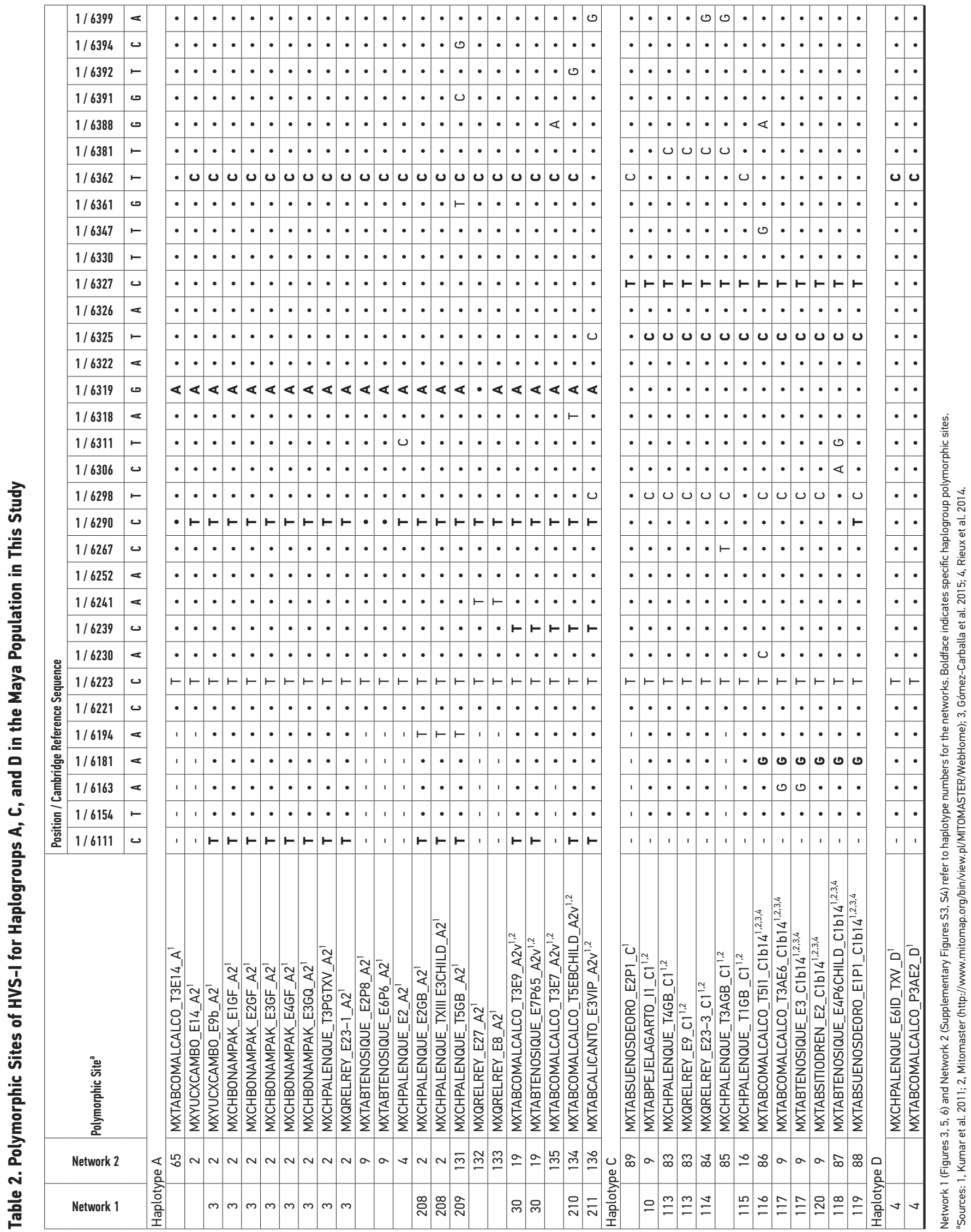




\section{Mismatch Distribution}

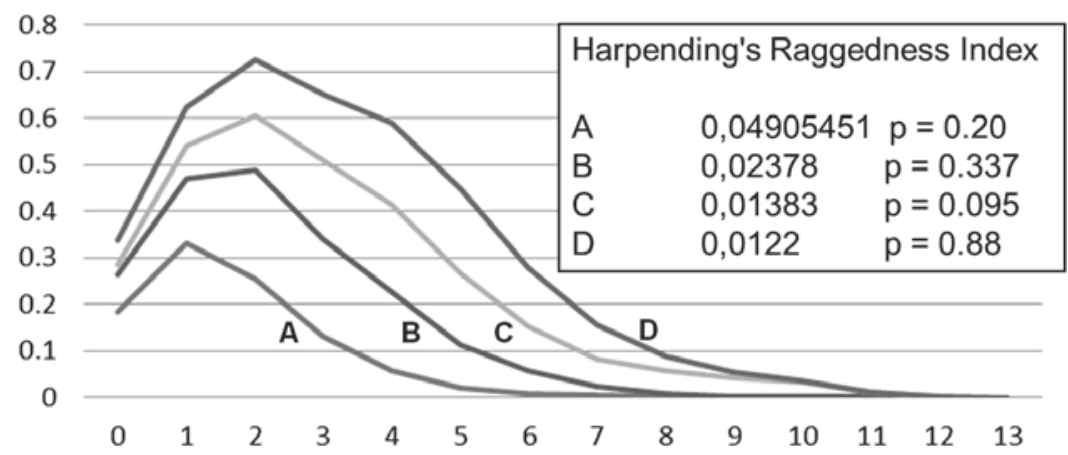

FIGURE 2. Mismatch distributions for haplogroups A, B, C, and $D$ with HVS-I data sets for all populations: demographic history inferred by mismatch distributions of the numbers of pairs of nucleotide differences among individuals within each of mtDNA haplogroup for the populations from the preHispanic Maya (Yucatan, Chiapas, and Tabasco), contemporary Maya (Yucatan, Guatemala, Honduras, and Belize), Asia, Bering Strait bridge, North America, and South America. The observed distributions were compared using the sudden population expansion model (Arlequin, version 3.5.1.2; Excoffier and Lischer 2010). Harpending's raggedness index values are also displayed.

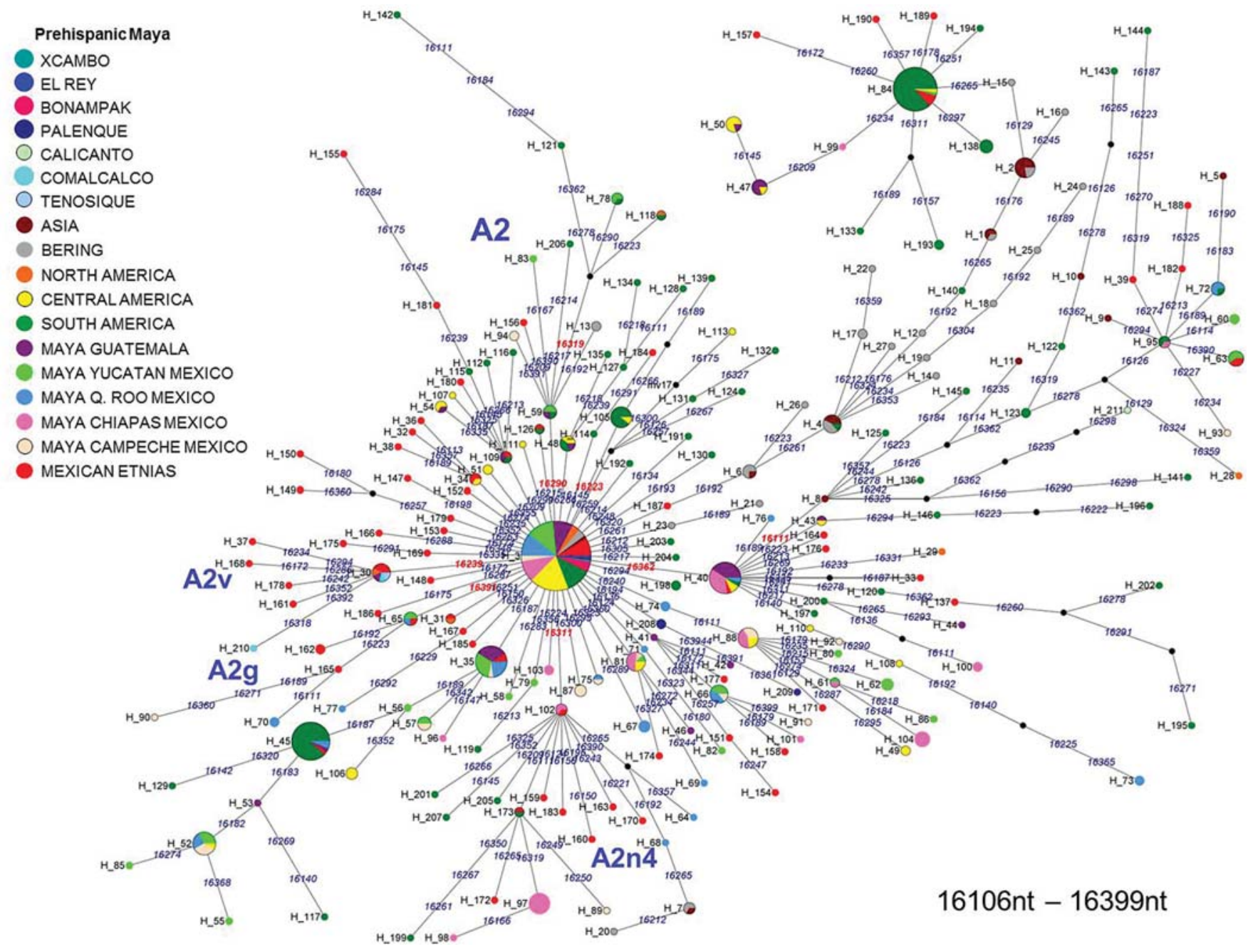

FIGURE 3. Haplotype network of mtDNA haplogroup A in the pre-Hispanic Maya, contemporary Maya (Yucatan, Guatemala, Honduras, and Belize), Asia, Beringia, North America, and South America. A phylogenetic network was constructed with the mtDNA sequences from nucleotides 16,106-16,399 using Network. The size of each circle is proportional to the number of individuals in each haplotype present in the data set (see Supplementary Table S1). The distances between the circles correspond to one mutation between haplotypes; otherwise, it is indicated by the numbers on the lines that connect haplotypes. Black dots on the branches represent inferred missing haplotypes (single nucleotide changes). 
Table 3. Haplotypes Shared at Various Locations in mtDNA Sequences of Pre-Hispanic and Contemporary Human Populations

\begin{tabular}{|c|c|c|c|c|c|}
\hline \multirow{3}{*}{ Haplogroup } & \multirow{3}{*}{ Time Period (CE) } & \multicolumn{4}{|c|}{ Haplotype Number } \\
\hline & & \multicolumn{2}{|c|}{ A } & \multirow{2}{*}{$\begin{array}{c}\text { C } \\
10\end{array}$} & \multirow{2}{*}{ D } \\
\hline & & H3 & H30 & & \\
\hline Xcambo (E9b_A2, E14_A2) & $250-550$ & - & & & \\
\hline Bonampak (E1GF_A2, E2GF_A2, E3GF_A2, E4GF_A2, E3GQ_A2) & $580-800$ & - & & & \\
\hline Palenque (T3PGTXV_A2) & $750-800$ & - & & & \\
\hline El Rey Quintana Roo (E23-1_A2) & $1200-1500$ & - & & & \\
\hline Pre-Columbian Guane & $1090 \pm 70$ & - & & & \\
\hline Chibchan: Costa Rica (Rama), Panama (Maleku, Guaymi), and Colombia & Contemporary & - & & & \\
\hline $\begin{array}{l}\text { Ecuador (Kayapa), Bolivia (Yuracare), Uruguay (Tacuarembó), Peru (Quechua), } \\
\text { Brazil (Xavante) }\end{array}$ & Contemporary & • & & & \\
\hline Chile (Archaeological Cemeteries) & 1900 BCE-1900 CE & • & & & \\
\hline Mexico City (Nahualt Zitlala, Ixhuatlancillo) & Contemporary & $\cdot$ & & & \\
\hline Mexico City (Nahualt Xochimilco) & Contemporary & - & - & & \\
\hline Michoacan (Purépecha), Oaxaca (Mixe) & Contemporary & $\cdot$ & & & \\
\hline Maya: Yucatan, Quintana Roo, Chiapas (Tzotzil, Tojolobal) & Contemporary & $\cdot$ & & - & \\
\hline Campeche (Maya) & Contemporary & • & & & \\
\hline Guatemala (Maya) & Contemporary & $\cdot$ & - & & \\
\hline Guatemala (Ladino) & Contemporary & • & & & \\
\hline Nayarit (Cora) & Contemporary & • & & • & \\
\hline USA (Native Americans, Hispanic) & Contemporary & $\cdot$ & & - & \\
\hline Arizona (Hualapai) & Contemporary & & & - & \\
\hline California (Native American) & Contemporary & & - & • & \\
\hline Northern Asia (Mongolia, Siberia, Russia, and China) & Contemporary & $\cdot$ & & & $\cdot$ \\
\hline Siberia (Chukchi Eskimo) & Contemporary & - & & & \\
\hline China (Han) & Contemporary & & & • & - \\
\hline Ojinaga, Juarez & Contemporary & • & - & - & \\
\hline Aleutian archipelago (Aleut) & Contemporary & $\cdot$ & & & \\
\hline Comalcalco (T3E9) & $700-900$ & & - & & \\
\hline Tenosique (E7P65) & $700-900$ & & • & & \\
\hline Quechua: Peru (Yancash, Yuncay, Tupe, Tayacaja, Arquipa) & Contemporary & $\cdot$ & & - & \\
\hline Peje Lagarto (I1_C1) & $700-900$ & & & - & \\
\hline Cuba (Ciboney), Hualapay & $40 \mathrm{BCE}$ & & & - & $\cdot$ \\
\hline $\begin{array}{l}\text { Sonora (Pimas), Venezuela (Guahibo, Amazon, Wayuu), Colombia (Wayuu), } \\
\text { Bolivia (Movima), Peru (Quechua, Aymara), Brazil and Venezuela (Shamatari), } \\
\text { Brazil (Zoró, Xikrin, Tibus), Chile (Pehuenche, Aonikenk) }\end{array}$ & Contemporary & & & • & \\
\hline Palenque (E6ID TXV_D) & $750-800$ & & & & - \\
\hline Comalcalco (P3AE2_D) & $700-900$ & & & & $\cdot$ \\
\hline Brazil (Maranhão, SE, N), & Contemporary & & & & - \\
\hline
\end{tabular}

(E7P65) and with contemporary groups of Native Americans and from Juarez and Xochimilco in Mexico City in this network analysis of sequences from nucleotides 16106-16399 (Figure 3, Tables 2, 3; see also Supplementary Table S1). Haplotype H208 was shared by the samples from Palenque E2GB and Palenque TXIII_E3.

The DNA of samples from Comalcalco (T3E14 and T3E7), Xcambo (E14), Palenque (E2), El Rey (E27 and E8), and Tenosique (E2P8 and E6P6) demonstrated greater damage, and the sequences obtained were from nucleotides 16215-16399. Consequently, a second network analysis was performed (see Supplementary Figure S3 and Table S1). Furthermore, the sequences from the archaeological site "La Purnia" in Santander, Colombia, were included in this second analysis because these sequences encompassed the HVS-I region from nucleotides 16210-16364 (Casas-Vargas et al. 2011). The results showed that haplotype $\mathrm{H} 2$ included the pre-Hispanic samples and contemporary sequences containing haplotype H3 in the first analysis and 


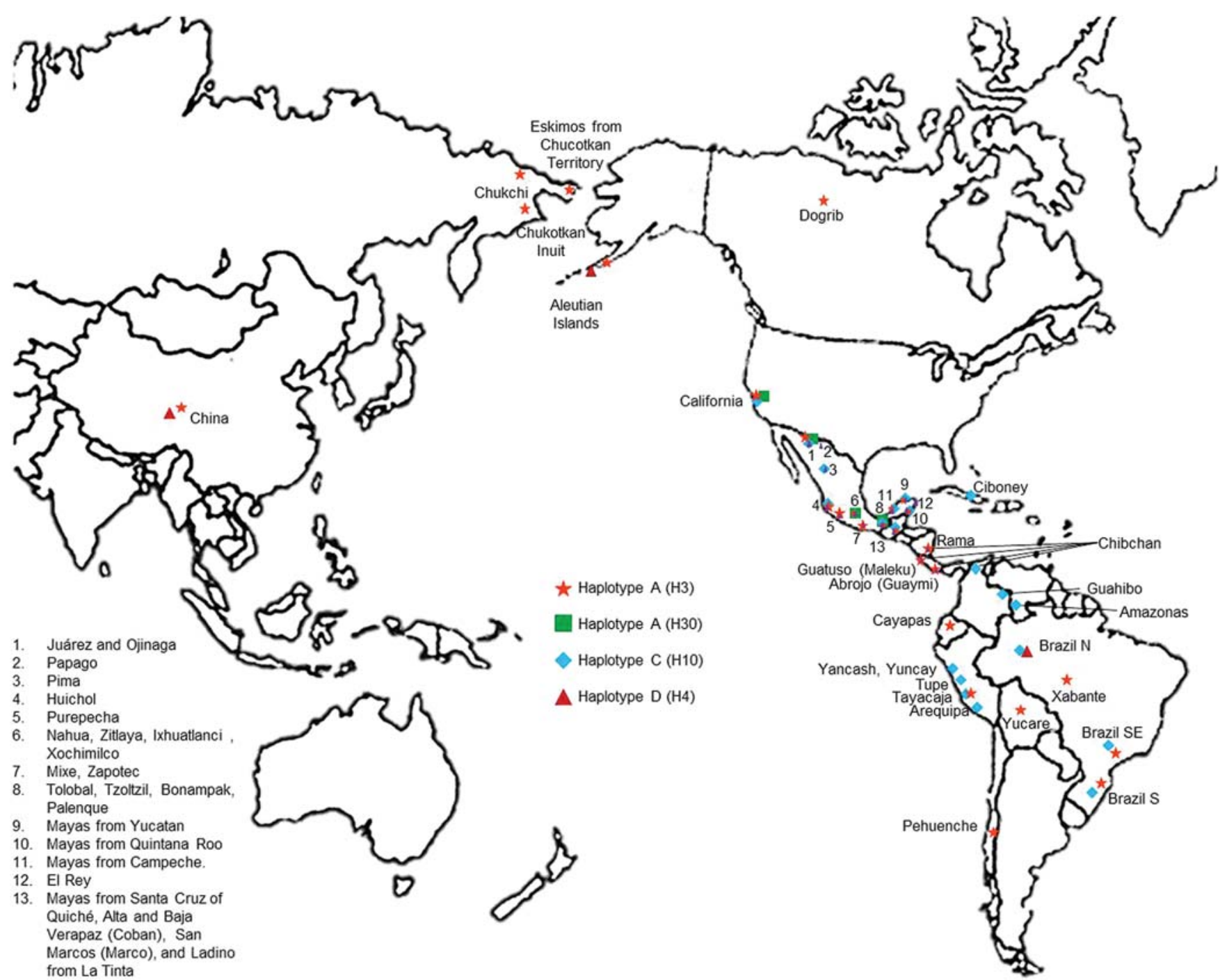

FIGURE 4. Geographic distribution of shared mtDNA haplotypes between the Maya pre-Hispanic populations in this study and those reported previously for contemporary and pre-Hispanic groups (see Supplementary Table S1) from Asia, Beringia, and America.

Xcambo E9b and Palenque E2GB and TXIII_E3 individuals, the Pre-Columbian Guane, and the contemporary sequences displayed in Table 3. Table 2 (see also Supplementary Figure S3 and Table S1) shows these results, and Figure 4 shows the geographic distribution of this haplotype. Haplotype H65 was shared by pre-Hispanic sample T3E14 from Comalcalco and two Maya samples from La Tinta, Guatemala. Haplotypes for the pre-Hispanic samples from Paleque (T5GB), El Rey Quintana Roo (E27 and E8), Comalcalco (T5EB and T3E7), and Calicanto (E3VIP) are shown in Table 2 (see also Supplementary Figure S3). These samples did not cluster with any of the contemporary sequences, likely due to a low frequency of these haplotypes or missing haplotypes from the contemporary Native American populations.

Furthermore, the network analysis for haplogroup A revealed that, among 23 samples, one contained haplogroup A (T3E14 from Comalcalco, Tabasco); haplogroup A2 was detected in all individuals from Bonampak, Palenque (T3PGTXV, E2GB, T5GB, TXIII, E2), El Rey Quintana Roo (E23-1, E27, E8), and Tenosique (E2P8 and E6P6); and haplogroup $\mathrm{A} 2 \mathrm{v}$ that has been detected in contemporary populations from Central America (Kumar et al. 2011) was identified in five samples: three from Comalcalco (T5EBCHILD, T3E9, T3E7), 
one from Tenosique (E7P65), and one from Calicanto (E3VIP), all from Tabasco (Table 2).

A previous analysis of the biological relationship between Central and South American Chibchan-speaking populations using mtDNA sequences demonstrated the presence of a shared maternal genetic structure between Central American Chibchan (Melton et al. 2013), Maya populations, and northern South American Chibchan speakers (Melton et al. 2007). The maternal lineage affinity between the Chibchan and Maya groups was based on one contemporary Maya group from Guatemala (Boles et al. 1995; Melton et al. 2007, 2013). However, this association has now been confirmed in this study analyzing the sequences of pre-Hispanic Mexican Maya and sequences from the Caribbean Islands, Colombia, and contemporary Maya groups from Mexico and Guatemala, as well as Central and South American Chibchan speakers from previous reports (Table 3). Table 3 shows haplotype sharing among the pre-Hispanic Maya groups, contemporary Maya, and Chibchan populations from central and South America.

\section{Network Analysis for Haplogroup C}

Sequence analyses of 13 out of 38 pre-Hispanic Maya individuals containing haplogroup $\mathrm{C}$ revealed a total of 11 haplotypes (Table 2). One sample belonged to haplogroup $\mathrm{C}$; six were found in haplogroup $\mathrm{Cl}$; and six were identified as haplogroup

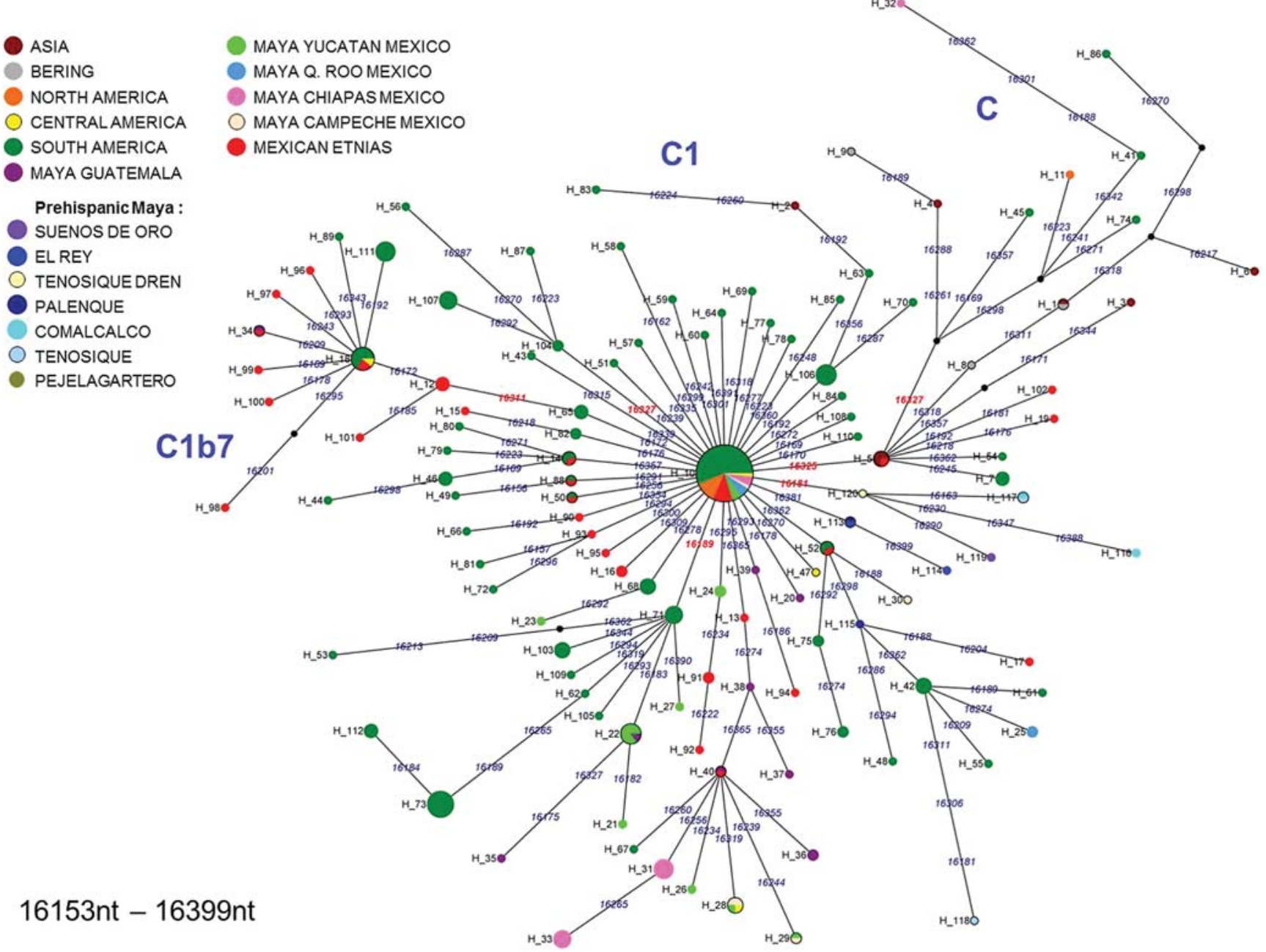

FIGURE 5. Haplotype network of mtDNA haplogroup C in the pre-Hispanic Maya, contemporary Maya (Yucatan, Guatemala, Honduras, and Belize), Asia, Beringia, North America, and South America. A phylogenetic network was constructed using the mtDNA sequences from nucleotides $16153-16399$ with Network The size of each circle is proportional to the number of individuals in each haplotype present in the data set (see Supplementary Table S1). The distances between the circles correspond to one mutation between the haplotypes; otherwise, it is indicated by the numbers on the lines that connect haplotypes. Black dots on the branches represent inferred missing haplotypes (single nucleotide changes). 
Clbl4 (Figures 1, 4, 5; Table 2; see also Supplementary Figure S4).

The median network analysis for haplogroup $\mathrm{C}$, which was based on the sequences from nucleotides 16153-16399, revealed one primary diversification center, lineage H10 (haplogroup $\mathrm{Cl}$ ), which clustered the pre-Hispanic sample from Peje Lagarto (I1) and Ciboney (CF5), Cuba, and the contemporary populations shown in Table 3 from the United States, native Mexicans including Mayans, and individuals from Guatemala, Brazil, Peru, and Colombia. A second lineage, H5, encompassed sequences from Asian and North American individuals with several haplotype diversifications. The pre-Hispanic samples from Palenque (T4GB) and El Rey Quintana Roo (E9) were found in haplotype H113, and the Comalcalco (T3AE) and Tenosique E3 samples shared haplotype H117. Haplotypes of individuals from El Rey Quintana Roo (E23), Palenque (T1GB), Comalcalco (T5Il), Tenosique (EN4P6), Sueños de Oro (E1P), and Dren (E2) are displayed in Table 2 and Figure 5. Haplotypes H116, H117, H119, and H120 clustered in the same branch and were classified as belonging to haplogroup Clbl4 based on the presence of a G $>$ A transition at position 16181 (Gómez-Carballa et al. 2015; Kumar et al. 2011; Rieux et al. 2014) (Figure 5, Table 2).

Haplogroup Clb14 observed in the pre-Hispanic population from Tabasco (Table 2 ) is very infrequent in contemporary Native American populations. Specifically, this haplogroup was observed in three contemporary individuals: two Mexican Americans and one Zapotec (Gómez-Carballa et al. 2015; Kumar et al. 2011; Rieux et al. 2014). Decrease of this haplogroup in the contemporary population may be due to the reduction of the populations during the Spanish conquest. The sharing of haplogroup Clbl4 may suggest common ancestry of this pre-Hispanic Maya and the three contemporary Mexicans.

A second network analysis was constructed because the sequences of the pre-Hispanic samples from Palenque (T3AGB) and Sueños de Oro (E2P1) contained data from nucleotide positions 16213-16399 (see Supplementary Figure S4). Haplotypes of these two samples and Palenque T4GB and El Rey Quintana Roo (E9, E23) are displayed in Table 2 . This analysis displayed a main diversification center, lineage H9, containing sequences from pre-Hispanic individuals from
Peje Lagarto (I1), Comalcalco (T3AE6), Tenosique (E3), and Dren (E2) in this study, Ciboney from Cuba, and the contemporary individuals as in the first analysis containing haplotype H10 (Tables 2, 3; see also Supplementary Figure S4 and Table S1). Haplotypes 84-89 were not observed in the database included in this study. However, Sueños de Oro E1P1 demonstrated an identity of 99\% with an individual from Texas, suggesting that these haplotypes are rare and not represented in recent studies, or they are not present in contemporary populations. These results support the notion that the Maya population spread to Central and South America. No haplogroup $C$ was reported in the PreColumbian Guane group (Casas-Vargas et al. 2011). The geographic distribution and shared haplotypes are shown in Figure 4 and Table 3, respectively.

\section{Network Analysis for Haplogroup D}

The sequence analysis showed that, of the two preHispanic samples, one individual from Palenque (E6ID) and one from Comalcalco (P3AE2) belonged to haplogroup D (Figure 6, Table 2) based on the absence of the polymorphisms diagnostic of other haplogroups and the presence of the frequent $\mathrm{T}>\mathrm{C}$ and $\mathrm{C}>\mathrm{T}$ transitions proposed by Torroni et al. (1993) at positions 16223 and 16362, respectively. The D1 haplogroup found throughout the Americas was absent in the samples used in this study (Figure 6 , Table 2), potentially due to the low frequency of this haplogroup in our pre-Hispanic population.

The median network haplogroup D analysis in the HVS-I region, including nucleotide positions 16153-16399 (Figure 6), displayed three main diversification centers: haplotype H4 (haplogroup D) encompassing the individuals from the pre-Hispanic samples Palenque E6ID_TXV and Comalcalco P3AE2 in this study, plus one sequence from Ciboney, and contemporary individuals from northern Brazil, China, and northern Asia, as shown in Table 3; haplogroups D1 of haplotypes are displayed in Figure 6 (see also Supplementary Table S1). The geographic distribution of the pre-Hispanic and contemporary samples that shared this haplotype $\mathrm{H} 4$ is displayed in Figure 4. These results suggest that the ancestors of the pre-Hispanic individuals containing haplotype H4 originated from China and northern Asia and subsequently spread to Cuba and South America. The main diversification centers of the American 


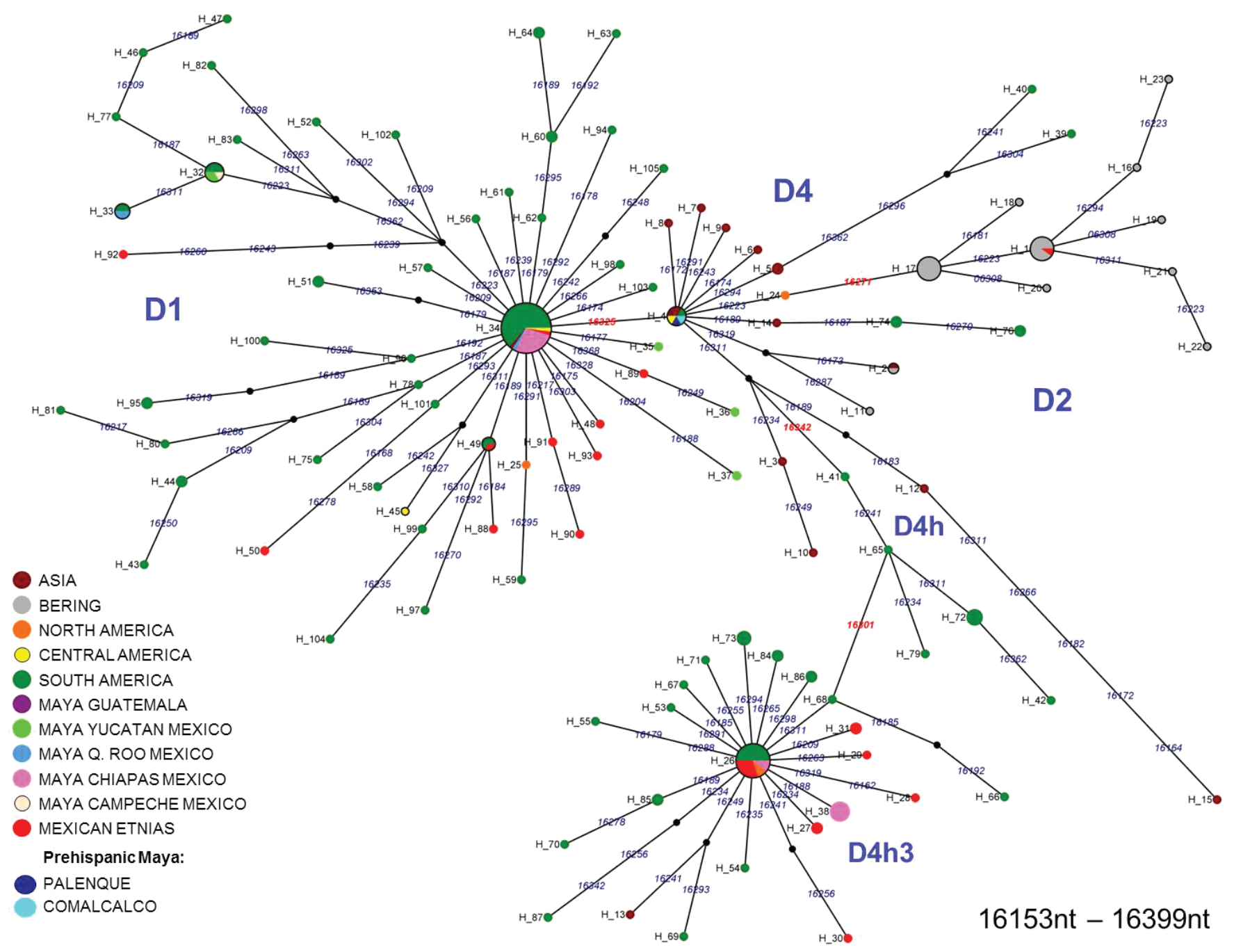

FIGURE 6. Haplotype network of mtDNA haplogroup D in the pre-Hispanic Maya, contemporary Maya (Yucatan, Guatemala, Honduras, and Belize), Asia, Beringia, North America, and South America. A phylogenetic network was constructed with the mtDNA sequences from nucleotides 16153-16399 using Network, version 4.6.1.1. The size of each circle is proportional to the number of individuals in each haplotype present in the data set (see Supplementary Table S1). Distances between the circles correspond to one mutation between the haplotypes; otherwise, it is indicated. Black dots on the branches represent inferred missing haplotypes (single nucleotide changes).

populations were grouped in haplogroup D (H4), D1 (H34), D4h3 (H26), and D2 (H17 and H1), which included sequences from Aleuts (Bering), Eskimo, Evenk, Chukchi, and Nahua individuals (Figure 6; see also Supplementary Table S1). These results also support the maternal linage affinity between the pre-Hispanic Mexican populations in this study and the pre-Hispanic Ciboney from Cuba, suggesting shared regional haplotypes indicating a shared genetic ancestry. This may point to more regional interaction between populations in the circumCaribbean region than previously demonstrated.
A second analysis of haplogroup D sequences from nucleotides 16181-16399 was conducted including the pre-Hispanic Guane group from Colombia in the analysis to evaluate the presence of a maternal linage relationship between the preHispanic Guane from Colombia (Casas-Vargas et al. 2011) and Mexican pre-Hispanic Maya individuals (results not shown). The two sequences from the pre-Hispanic Maya did not contained the same haplotype, indicating that these individuals did not share a common ancestor.

The results of network analysis of the haplo- 
Table 4. Analysis of Molecular Variance for mtDNA Control Region by Time Scale

\begin{tabular}{|c|c|c|c|c|c|}
\hline Source of Variation ${ }^{a}$ & $\mathrm{df}$ & \multicolumn{2}{|c|}{ Sum of Squares } & ariance Components ${ }^{b}$ & Percentage of Variation \\
\hline Among groups & 3 & \multicolumn{2}{|l|}{12.552} & $.03295 V_{a}$ & 1.23 \\
\hline Among populations & 8 & \multicolumn{2}{|l|}{52.837} & $.13289 V_{b}$ & 4.98 \\
\hline Within populations & 313 & \multicolumn{2}{|c|}{783.512} & $.50323 V_{c}$ & 93.79 \\
\hline Total & 324 & \multicolumn{2}{|c|}{848.902} & 66907 & \\
\hline Genetic Structure Test (four groups) ${ }^{c}$ & \multicolumn{2}{|c|}{$P($ rand. value $>$ obs. value $)$} & $P($ rand. value < obs. value $)$ & $P($ rand. value $=0 \mathrm{bs}$. value $)$ & $P$-value \\
\hline$V_{c}$ and $F_{S T}$ & & & 0.00000 & 0.00000 & $0.00000+-0.00000$ \\
\hline$V_{b}$ and $F_{S C}$ & 0.00 & & & 0.00000 & $0.00000+-0.00000$ \\
\hline$V_{a}$ and $F_{C T}$ & 0.13 & & & 0.00000 & $0.13685+-0.01012$ \\
\hline
\end{tabular}

Data are for early 250-550 CE (Xcambo); middle 580-900 CE (Bonampak, Palenque, Comalcalco, Tenosique, Sueños de Oro, Calicanto, Peje Lagarto); late 1200-1500 CE (El Ray Quintana Roo); and contemporary Mexican Maya populations.

${ }^{a}$ Fixation index $=0.05041 ; F_{S T}=0.06213 ; F_{C T}=0.01234$

${ }^{b} V_{a}$, variation between groups; $V_{b}$, variation among populations; $V_{c}$, variation within population.

'Distance method: Pairwise difference significance tests (1,023 permutations). rand., random; obs., observed.

group $\mathrm{A}, \mathrm{C}$, and $\mathrm{D}$ lineages in the pre-Hispanic Maya were consistent with the hypothesis that the direct ancestors of Native Americans were a hybrid of different Siberian groups that had migrated to eastern Beringia at different times and following different routes (Figure 4) (Kunz and Reanier 1994; Perego et al., 2010; Starikovskaya et al. 2005).

\section{Analysis of Molecular Variance by Time Scale}

Results for analysis of molecular variance using mtDNA HVS-I data that separated Maya population into four groups: (a) early 250-550 CE (Xcambo), (b) middle 580-900 CE (Bonampak, Palenque, Comalcalco, Tenosique, Sueños de Oro, Calicanto, Peje Lagarto), (c) late 1200-1500 CE (El Rey Quintana Roo), and (d) contemporary Mexican Maya base on time scale are summarized in Table 4 . The lowest amount of observed variation was $1.23 \%$ for mtDNA HVS-I among groups $\left(F_{C T}=0.01234\right)$, whereas within-group analysis explained $4.98 \%$ $\left(F_{S C}=0.05041\right)$ of variation. Most variation, $93.79 \%$ $\left(F_{S T}=0.06213\right)$, was found within populations.

\section{Sequence Diversity Analysis (Demographic Analysis)}

The results of the diversity indices and neutrality tests are shown in Table 5 for all contemporary and pre-Hispanic populations. Similar diversity values were obtained for all populations analyzed in this study. Fu's Fs was negative and significant for all six populations. These results suggest the presence of rare alleles at low frequencies or population expansion after a recent bottleneck.

\section{Analysis by Multidimensional Scaling (MDS)}

\section{MDS of Pre-Hispanic and Modern Populations}

To visualize the relationships between the preHispanic Mayas in this study and the contemporary populations from Asia, Beringia, and North and South America based on the HVS-I mtDNA sequence data, MDS plots were constructed using the pairwise $F_{S T}$ values (Figure 7). The MDS plot reveals that the genetic distances between the pre-Hispanic and contemporary Maya populations were smaller than between the pre-Hispanic and Beringian, Asian, North or South American groups (Figure 7). The distance between North and South America was also shorter than for the other groups, indicating a closer affiliation. The distances between the ancient Maya population and the contemporary Maya, Asians, Beringians, and North and South Americans can be explained by the shared haplotypes from haplogroups A, C, and $\mathrm{D}$ with the contemporary populations (Figures 3-6, Table 3). Furthermore, the pre-Hispanic Maya populations in this study displayed a high frequency of haplogroup A (60.53\%), followed by haplogroup C $(34.21 \%)$ and an extremely low frequency of haplogroup D (5.26\%; Figure 1).

\section{MDS of Pre-Hispanic Populations}

The MDS plot comparing the pre-Hispanic populations revealed that Tenosique, Comalcalco, El Rey Quintana Roo, and Palenque clustered together (Figure 8), and Yucatan and Bonampak were located together, whereas Tabasco, Ciboney, and 
Table 5. Diversity Indices and Neutrality Tests for Six Populations: Pre-Hispanic Maya, Contemporary Maya, North America, South America, Beringia, and Asia

\begin{tabular}{|c|c|c|c|c|c|c|c|c|}
\hline \multirow{2}{*}{ Measure } & \multicolumn{6}{|c|}{ Population (Samples Belonging to Haplogroups A, B, C, and D) } & \multirow[b]{2}{*}{ Mean } & \multirow{2}{*}{ SD } \\
\hline & Ancient Maya & Contemporary Maya & North America & South America & Beringia & Asia & & \\
\hline Sample size & 40 & 331 & 310 & 405 & 63 & 47 & 199.33333 & 166.77010 \\
\hline $\begin{array}{l}\text { Nucleotide } \\
\text { diversity (п) }\end{array}$ & 4.64103 & 3.97836 & 4.59668 & 5.17376 & 3.18382 & 3.80481 & 4.22974 & 0.71171 \\
\hline$\theta_{k}(95 \% \mathrm{Cl})$ & $\begin{array}{l}21.69131 \\
(11.77983- \\
40.13327\end{array}$ & $\begin{array}{l}26.25052 \\
(19.68381- \\
34.6986)\end{array}$ & $\begin{array}{l}64.64430 \\
(50.52623- \\
82.41044\end{array}$ & $\begin{array}{l}155.96344 \\
(127.08540- \\
191.28236)\end{array}$ & $\begin{array}{l}13.68336 \\
(8.09424- \\
22.81939\end{array}$ & $\begin{array}{l}28.27285 \\
(16.01871- \\
50.23837)\end{array}$ & $\begin{array}{l}51.75096 \\
(38.86470- \\
70.26374)\end{array}$ & $\begin{array}{l}54.00129 \\
(45.80205- \\
62.63826\end{array}$ \\
\hline$\theta_{s}(\mathrm{SD})$ & \begin{tabular}{|l|}
6.34765 \\
$(2.16339)$ \\
\end{tabular} & $\begin{array}{l}8.31005 \\
(1.98286) \\
\end{array}$ & \begin{tabular}{|l|}
10.93126 \\
$(2.52823)$ \\
\end{tabular} & \begin{tabular}{|l|}
13.37413 \\
$(2.91478)$ \\
\end{tabular} & $\begin{array}{l}4.45633 \\
(1.49606) \\
\end{array}$ & \begin{tabular}{|l|l|}
6.33959 \\
$(2.10068)$ \\
\end{tabular} & \begin{tabular}{|l|}
8.29317 \\
$(2.19767)$ \\
\end{tabular} & \begin{tabular}{|l|}
3.31960 \\
$(0.48425)$ \\
\end{tabular} \\
\hline$\theta_{n}(S D)$ & \begin{tabular}{|l|}
4.64103 \\
$(2.58215)$ \\
\end{tabular} & \begin{tabular}{|l|l|}
3.97836 \\
$(2.20743)$ \\
\end{tabular} & \begin{tabular}{|l|l}
4.59668 \\
$(2.50362)$
\end{tabular} & \begin{tabular}{|l|}
5.17376 \\
$(2.77688)$ \\
\end{tabular} & \begin{tabular}{|l|}
3.18382 \\
$(1.85000)$ \\
\end{tabular} & \begin{tabular}{|l|}
3.80481 \\
$(2.16443)$ \\
\end{tabular} & \begin{tabular}{|l|}
4.22974 \\
$(2.34742)$ \\
\end{tabular} & \begin{tabular}{|l|}
0.71171 \\
$(0.33599)$ \\
\end{tabular} \\
\hline Tajima's $D$ & -0.91697 & -1.49457 & -1.70157 & -1.79209 & -0.88503 & -1.33424 & -1.35408 & 0.38570 \\
\hline$P$-value ${ }^{a}$ & 0.19500 & 0.03300 & 0.01300 & 0.00500 & 0.18900 & 0.06800 & 0.08383 & 0.08659 \\
\hline Fu's Fs & -11.51058 & -25.36427 & -25.13194 & -24.77965 & -13.05111 & -20.96007 & -20.13294 & 6.31079 \\
\hline$P$-value ${ }^{a}$ & 0.00100 & 0.00000 & 0.00000 & 0.00000 & 0.00100 & 0.00000 & 0.00033 & 0.00052 \\
\hline
\end{tabular}

a Significant $P$-values $<0.05$ (for Tajima's $D$ ) and $<0.02$ (for Fu's $F s$ ).

Chile groups clustered separately. The ancient populations from Ciboney, Cuba, and Chile are expected to be separate from the other populations because of their geographic locations and high frequency of haplogroups C and D in Ciboney and B and D in Chile. Peje Lagarto and Calicanto were separated from the main group because of the small sample size and geographic location (Figure 1). The clustering together of Xcambo and Bonampak can be due to Preclassic period origin of both populations. We suggest that the individuals from Xcambo (250-550 CE) migrated to Bonampak (580-800 CE) at that time.

\section{MDS of Pre-Hispanic and Ancient Populations}

When the ancient populations are compared with the contemporary Maya populations by the MDS plot (Figure 9), the contemporary populations from Quintana Roo, Yucatan, Guatemala, Campeche, and Tzotzil clustered together; however, Bonampak and Xcambo were also closely related, Tenosique and Comalcalco were equidistant to the Tzotzil

FIGURE 7 (top). Multidimensional scaling between preHispanic Maya, contemporary Maya (Yucatan, Guatemala, Honduras, and Belize), Asia, Beringia, North America, and South America. The genetic affinities (see Supplementary Table S1) were analyzed by MDS.

FIGURE 8 (bottom). Multidimensional scaling among ancient Maya populations. The genetic affinities among the preHispanic Maya and ancient populations from Chile and Cuba (see Supplementary Table S1) were analyzed by MDS.
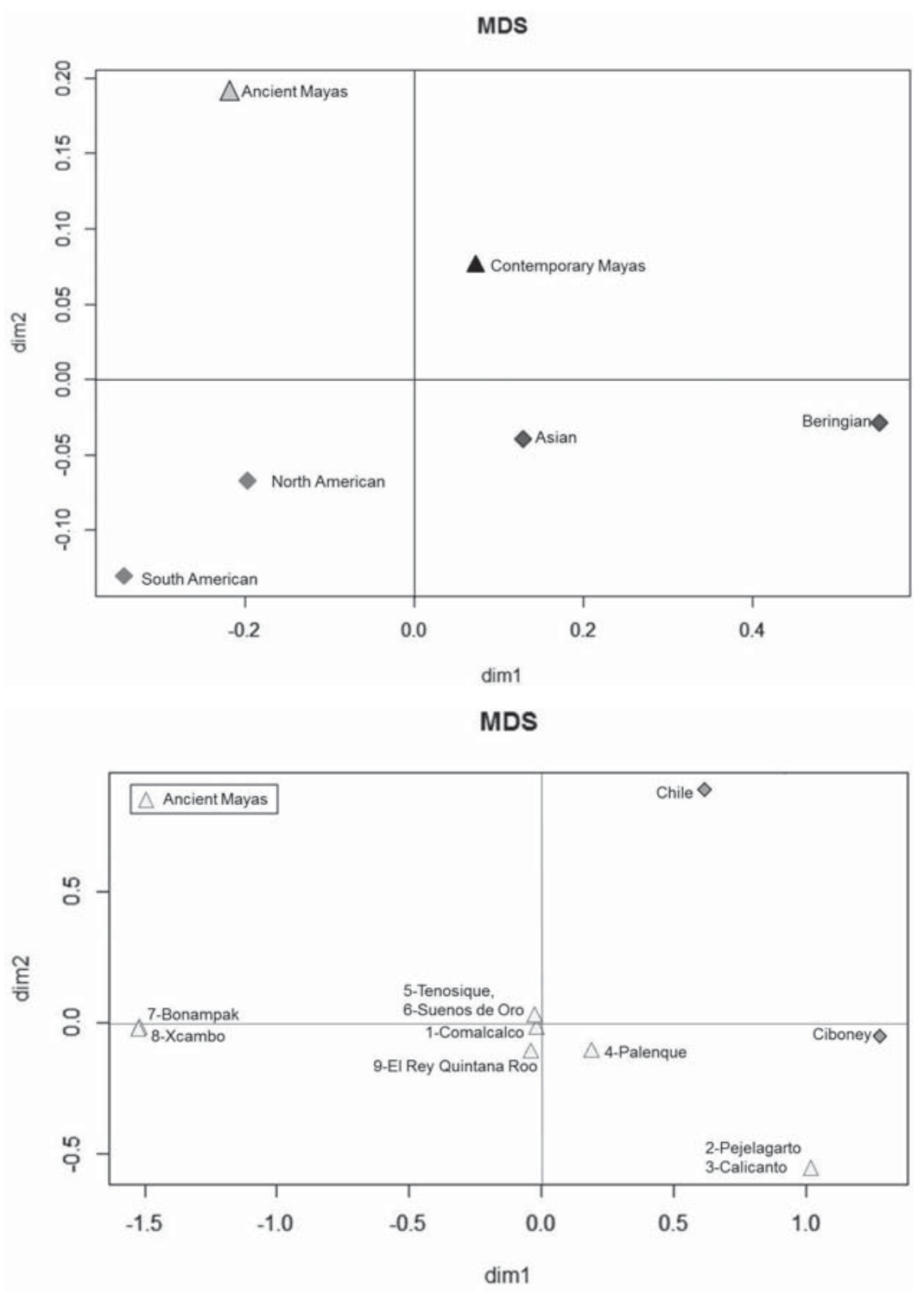


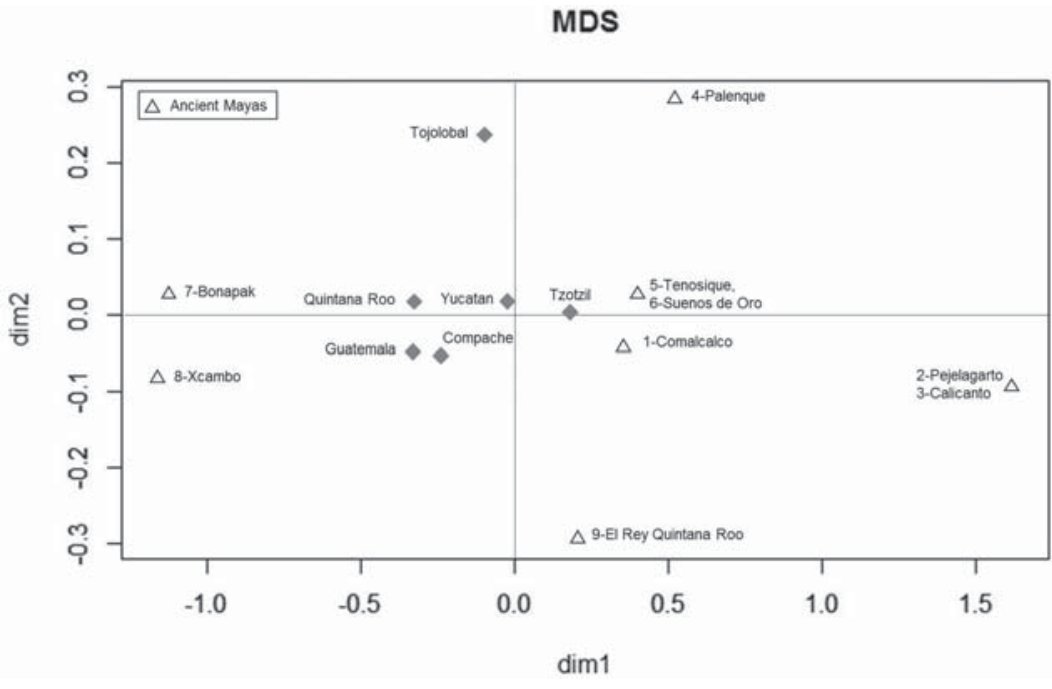

FIGURE 9. Multidimensional scaling between the pre-Hispanic Maya and contemporary Maya (Mexico, Guatemala, Honduras, and Belize). The genetic affinities (see Supplementary Table S1) were analyzed by MDS.

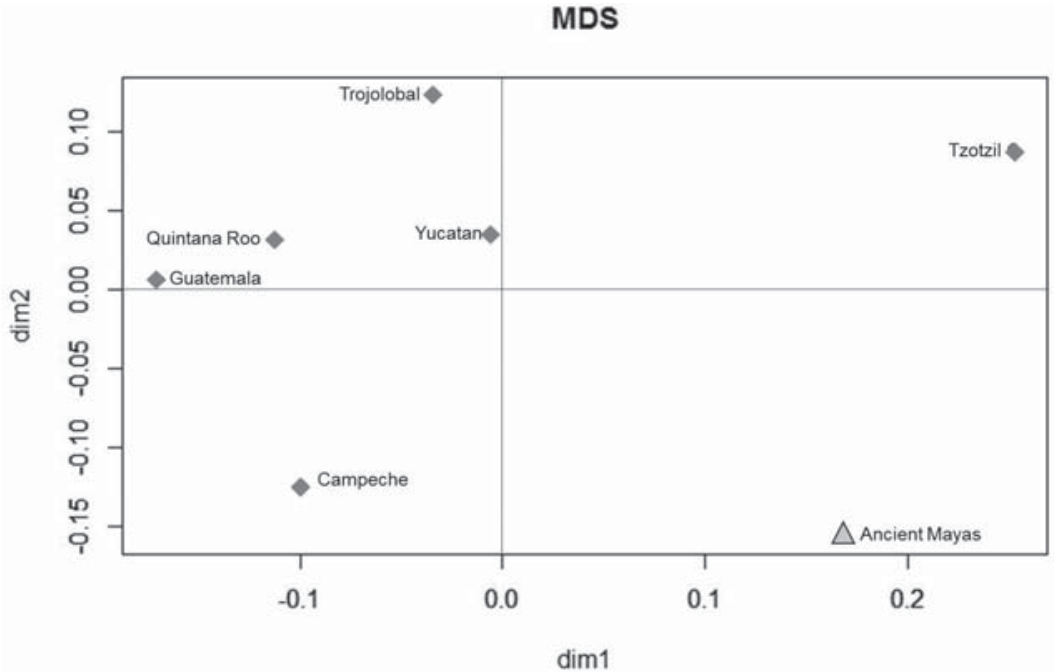

FIGURE 10. Multidimensional scaling between all ancient Maya populations as a group and the contemporary Maya populations by city. The genetic affinities (see Supplementary Table S1) were analyzed by MDS
pre-Hispanic Maya groups in this study had a high frequency of haplogroup A, similar to that found in contemporary Maya (González-Martín et al. 2015; Söchtig et al. 2015) and Aleuts from the Commander Islands (Crawford et al. 2010; Derbeneva et al. 2002).

\section{MDS of Pre-Hispanic and Modern Mayan Populations}

A comparison of all pre-Hispanic Mayan populations as one group with the contemporary Mayan populations/group by MDS plot revealed that the ancient populations were separated from the contemporary populations (Figure 10), probably due to the differences in haplotype composition resulting from recent migrations into Maya populations, consistent with the history of the Maya populations, which suffered different invasions by other populations, such as the Nahua of Uto-Aztecan affiliation, as well as recent migrations out of Maya areas. The ancient Maya populations in this study contained a high frequency of haplogroup A (A, $\mathrm{A} 2, \mathrm{~A} 2 \mathrm{v})$, followed by haplogroup $\mathrm{C}(\mathrm{Cl}$ and $\mathrm{Clb} 14)$, a very low frequency of haplogroup $\mathrm{D}$, and the absence of haplogroup B. Most contemporary indigenous populations from Mexico contain all four haplogroups in different proportions (PeñalozaEspinosa et al. 2007), although haplogroup A2 exhibits the highest frequency (Santos et al. 1994, 1996; Torroni et al. 1994). The high frequency of haplogroup A2 in the pre-Hispanic Maya populations is shared with the Asian, Siberian Eskimo, and Chukchi-Eskimo groups (Crawford et al. 2010; Crawford and Beaty 2013) and is probably due to a shared common ancestor.

\section{Mitochondrial Haplogroup Frequencies}

In general, the mitochondrial haplogroup frequencies differed substantially between the Southwest and Mesoamerican populations; haplogroup B was very common in the Southwest populations (USA), which rarely exhibited mitochondrial haplogroup A (Kemp and Schurr 2010). However, there were some exceptions, such as the Tarahumara. Additionally, haplogroup B was much less common in Mesoamerican populations, in which haplogroup A predominated (Kemp et al. 2010). However, the Nahua-Atocpan, a Mesoamerican population, exhibited slightly more haplogroup $B$ than haplogroup A (Kemp et al. 2010), the Tojolabal Maya population exhibited a higher frequency of 
haplogroup B than haplogroup A (González-Martín et al. 2015), and the ancient bones collected in a Quiché Indian village, located close to the provincial capital of Santa Cruz de Quiché, revealed the presence of 16 different mtDNA haplotypes, among which haplogroup B has the highest frequency (Boles et al. 1995).

The pre-Hispanic Maya population of this study displayed a high frequency of haplogroup A (60.53\%), followed by haplogroup C (34.21\%), a very low frequency of haplogroup D (5.26\%), and the complete absence of haplogroup B. Similar haplogroup frequencies have also been observed in the Central American Chibchan populations Kori and Arsario (Melton et al. 2013). Similarly, haplogroup B was apparently absent in the Fuego-Patagonians and the aboriginal groups above latitude 55 in North America and Asia, suggesting that the initial Paleoindian settlers that migrated into South America might represent an independent migration event unrelated to the Clovis people, as suggested previously (Lalueza et al. 1997). However, Kemp et al. (2010) and Kumar et al. (2011) suggested an early coastal migration. Similarly, present-day Amerindian populations inhabiting the Caribbean region of Colombia either did not carry or had lower frequencies of haplogroup B (Kogui 0\%, Arhuaco and Chimila 4.8\%, Arsario 12.5\%, and Wayuu 17.6\%), while the predominant haplogroup A was followed by haplogroup C (Yunis and Yunis 2013). Analysis of lower Central American Chibchan population mtDNA diversity has shown high frequencies of haplogroup A2 and B4 (Melton et al. 2007, 2013), while those from northern South America mirror the ancient Maya, with high frequencies of haplogroup A and moderate amounts of haplogroup C. The ancient population of Tipu from Belize has also been shown to carry haplogroup B (8\%) at a low frequency, although haplogroup C (64\%) was found in higher proportions compared with haplogroups D (28\%) and B (Elwess et al. 2015). Northern Colombians displayed lower frequencies of haplogroups B and D and a higher frequency of haplogroup B in western Colombia that declined toward eastern Colombia, whereas the Embed/ Wounan population from Panama has been reported to contain haplogroups A, B, C, and D (Kolman and Bermingham 1997). Similarly, the Tojolabal Maya population displayed a high frequency of haplogroup B2 (58.1\%) (González-Martín et al. 2015). In contrast, haplogroup B was absent in the aboriginal populations of northwestern and northern Siberia (Derbeneva et al. 2002), but it has been detected in populations restricted to the southwestern and south central periphery of the subcontinent (Derenko et al. 2000, 2003; Yunis and Yunis 2013). Haplogroup B mtDNA has also been detected in the skeletal remains exhumed from a 2,000-year-old cemetery in northern Mongolia (Keyser-Tracqui et al. 2003). Based on the results of this study and previous findings, the absence of haplogroup B in the pre-Hispanic Maya, the low frequency in most contemporary Maya, and its absence or low frequency in Colombia may suggest that the entry of haplogroup B into the Americas occurred independently of the other mitochondrial haplogroups (A, C, and D) during a later migration process, as suggested previously (Torroni et al. 1993; Starikovskaya et al. 1998; Lalueza et al. 1997). Therefore, it is possible that the Maya ancestors did not carry haplogroup B or may have lost it through genetic drift, as proposed previously for the populations of Tierra del Fuego (Lalueza et al. 1997; García-Bour et al. 2004).

\section{Haplotype Analysis and Shared Haplotypes}

The founding haplogroup A2, which was identified in the individuals in this study, has been reported to have a coalescence age of $19.5 \pm 1.3 \mathrm{kya} / 16.1 \pm 1.5$ kya, according to Kumar et al. (2011), calculated using the mutation rates reported by Mishmar et al. (2003) and Soares et al. (2009). A2v has a more recent coalescent time of 9.1/9.5 kya (Kumar et al. 2011), whereas haplogroups C, Cl, and Clbl4 have coalescent times of $27.37(19.55 ; 35.44)$ kya (Derenko et al. 2010), $21.4 \pm 2.7$ kya/16.4 \pm 1.5 kya (Kumar et al. 2011), and 12.4(7.7-17.3) kya (GómezCarballa et al. 2015), respectively. Haplotype H3 (haplogroup A2) from the pre-Hispanic populations in this study and the pre-Columbian Guane was shared with contemporary populations from North, Central, and South America, supporting the ancestral continuity of the present populations (Figures 3, 4; Table 3; see also Supplementary Figure S3 and Table S1). This finding supports the ethnogenesis of these Mexican Maya populations in pre-Hispanic times on a cultural and biological basis, in contrast to contemporary Maya populations (Söchtig et al. 2015). Haplogroup B was not detected in the pre-Hispanic populations of this 
study, although it has been reported in the preColumbian Guane population (Casas-Vargas et al. 2011). Therefore, to validate this finding, it will be important to pursue further studies of the preHispanic populations from the Maya area because the contemporary Tojolabal Maya population displayed a high frequency of haplogroup B2 (58.1\%) (González-Martín et al. 2015). Increasing the number of sequences from pre-Hispanic samples will be necessary to determine whether the absence of haplogroup B in the pre-Hispanic samples from the archaeological sites in this study reflects the absence or low frequency of this haplogroup.

Haplogroup D1 defined by the T>C, C>T, and $\mathrm{C}>\mathrm{T}$ transitions at positions 16223, 12325, and 16362, respectively (Kumar et al. 2011), in the preColumbian Guane differed from our findings, in which only the $\mathrm{T}>\mathrm{C}$ and $\mathrm{C}>\mathrm{T}$ transition at positions 16223 and 16362, respectively, specific for haplogroup D were identified (Torroni et al. 1993; Kumar et al. 2011). This haplogroup has also been found at low frequencies in the contemporary Maya populations from Quintana Roo, Yucatan, and Campeche, Mexico (González-Martín et al. 2015), and was absent in the Mexican pre-Hispanic populations.

Bodner et al. (2012) described two new subclades of the pan-American founder haplogroup D1 that were limited to the Southern Cone of South America. These findings were based on the limited geographic dispersal, high diversity of the Dlg and Dlj haplogroups, and calculated coalescence ages suggestive of a coastal and rapid initial extensive trans/Andean migration that may represent the genetic heritage of the pioneer settlers of South America and apparently is preserved in the presentday Mapuche people.

Haplogroup D, with an overall estimated coalescence time of 35-37 kya, based on the mutation rate used by Derenko et al. (2010), was identified in the pre-Hispanic samples from Palenque (E6ID_TXV) and Comalcalco (P3AE2), which have been represented by at least three D1, D4h3a, and D4elc branches in the Americas. The D1 haplogroup is found at a high frequency throughout the Americas, while D4h3a and D4elc are found at low frequencies (Kumar et al. 2011). These two samples lacked the 16325 mutation that is specific for haplogroup D1. It is not clear if this mutation has reverted in some Native American haplogroup D mtDNAs, such as the "Cayapa" haplotype BR53 (Alves-Silva et al. 2000), or if there is more than one Native American founder of this haplogroup, as suggested by Bandelt et al. (2003). The present-day variation in the haplogroup $C$ and D clades suggests that they expanded prior to the Last Glacial Maximum, with the oldest lineages present in eastern Asia (Derenko et al. 2010). Our network analysis results for haplogroup D support this hypothesis because haplotype $\mathrm{H} 4$ contained two of our sequences and the sequences from eastern Asia (Figure 6, Table 3; see also Supplementary Table S1). In addition, haplotype $\mathrm{H} 4$ also encompassed sequences from the pre-Hispanic samples from Ciboney and the contemporary individual from Brazil, supporting the dispersion of this haplotype from the Yucatan to Cuba or from Cuba to Yucatan during the pre-Hispanic era and to South America. Lalueza-Fox et al. (2003) suggested a migration of the Ciboneys from South America to the Caribbean Islands, although a migration in the opposite direction is also possible. This is also indicative of greater regional interaction among populations in the Circum-Caribbean region than previously demonstrated.

The pre-Hispanic Maya individuals from Xcambo (E9b), El Rey Quintana Roo (E23), Bonampak (E1GF, E2GF, E3GF, E4GF, E3GQ9), Palenque (T3PGTXV), Comalcalco (T3E9), and Tenosique (E7P65) all shared haplotype H3/H2 (Figure 3; see also Supplementary Figure S3 and Table S1) with the pre-Hispanic individuals from Ciboney, Cuba, pre-Columbian Guane, and the archaeological cemeteries from Chile; with contemporary people from northern Asia, Siberia, the Aleutian Islands, Dogrib, and Canada; and with Mexican Native Americans, Maya from Mexico and Guatemala, and native groups from Central and South America (Figures 3-6, Table 3; see also Supplementary Figures S3, S4). This haplotype sharing supports the migration of the Maya ancestors from Asia across the Bering Strait bridge, through the United States, and from northern Mexico to the Maya region. It is also likely that the genetic composition of pre-Hispanic Maya populations displays continuity with contemporary Maya populations because haplotype H3 of haplogroup A was also shared with different contemporary Maya populations. This finding also indicates that some of the contemporary Maya populations are descendants of both the 
original Maya population and other populations that migrated to these geographic areas, because some of the haplotypes found in the pre-Hispanic individuals were also detected in different proportions in contemporary Maya populations.

The Mexican Maya in this study displayed the highest frequency of haplogroup A, similar to the ancient Postclassic Aztecs from Tlatelolco (1450-1275 CE), Mexico (Kemp et al. 2005), the Maya from Xcaret, Mexico (González-Oliver et al. 2001), and the most modern Maya. In contrast, a 650-1200 CE Maya sample from Copán, Honduras, exhibited a high frequency of haplogroup C (Merriwether et al. 1997), and the 800-1100 CE from the Tommy site in the United States (Snow et al. 2010) showed a high frequency of haplogroup B, most closely resembling the ancient Anasazi at Fremont (Carlyle et al. 2000; LeBlanc et al. 2007) and the modern populations of Cora, Hualapai, Huichol, Jemez, Tarahumara, Tohono O'odham, and Zuni (Kemp et al. 2010), the Tojolabal Maya (González-Martín et al. 2015), and US Southwest and South America (Salas et al. 2009; Raff et al. 2011). Therefore, contemporary Maya are descendants of the pre-Hispanic Maya, and the ancestral Native Americans dispersed across North America approximately 13,000 years ago (Raghavan et al. 2015). Our results are consistent with other mtDNA data for the Guatemalan Maya region, demonstrating the presence of gene flow in the Mesoamerican area and a predominant unidirectional flow toward South America that most likely occurred during the Preclassic (1800 BCE-200 CE) and Classic (200-1000 CE) eras of the Mesoamerican chronology. This pattern of gene flow is in agreement with the development of the Maya civilization (Söchtig et al. 2015). Our results also support the expansion of maize with the human populations from the Mexican Gulf Coast to the south, as maize cultivation was dispersed from the lowland tropics of Tabasco earlier than 5,050 BCE to North and South America (Pohl et al. 2007; Merrill et al. 2009). This finding is consistent with the introduction of maize into the US Southwest prior to 2050 BCE (Merrill et al. 2009; Kemp et al. 2010; Kohler and Reese 2014), according to the population expansion from the Maya area to North and South America (Figure 4) through the long-distance migration of farmers from the Mexican Gulf Coast (Malhi et al. 2003). These results support the historically based migration theories supported by archaeological data.

\section{Genetic Admixture among Pre-Hispanic Populations}

Figure 1 and Table 2 show that HVS-I haplotype H3 (haplogroup A) is shared among the pre-Hispanic Maya from Comalcalco, Palenque, Tenosique, Sueños de Oro, Bonampak, Xcambo, and El Rey Quintana Roo; haplogroup A2v among Comalcalco, Tenosique, and Calicanto; haplotype H4 (haplogroup D) between Comalcalco and Palenque; and the rare haplogroup Clbl4 among Comalcalco, Tenosique, and Sueños de Oro, suggesting a genetic admixture, which appears to be more pronounced in Comalcalco. These results also indicate regional gene flow among the pre-Hispanic populations and regional interaction.

\section{Conclusions}

The results obtained in the present network analysis demonstrate the following. (a) Gene flow occurred within the Maya area, with a directional flow to South America in the Preclassic and Classic eras of the Mesoamerican chronology. (b) Historical documentation showing that the ancestors of Maya civilization entered the Yucatan Peninsula after the first movement of people from northern Asia into the Americas, with later migration of the Maya south to Central America and the Caribbean toward the northern region of South America, is supported by our analyses of contemporary and pre-Hispanic mtDNA. (c) Haplotypes H3 of haplogroup A and H4 of haplogroup D were shared among pre-Hispanic Maya, Ciboney, and Han Chinese, suggesting the migration of a common ancestor from East Asia to the Maya region of Mexico, Cuba, and Colombia. (d) Haplotype H3 of haplogroup A was shared among the pre-Hispanic Maya population and contemporary Maya from Mexico and Guatemala, suggesting maternal continuity of the pre-Hispanic Maya in the contemporary population. (e) Haplotypes of haplogroups A and $\mathrm{C}$ were shared among the pre-Hispanic Maya populations and native populations from Cuba (pre-Hispanic), Panama, Costa Rica, Colombia (pre-Hispanic and contemporary), Chile (archaeological cemeteries) Peru, and Brazil, and the Maya and Native American 
populations still carried the genetic imprint of the pre-Hispanic Maya. The results obtained for the diversity indices and neutrality tests (Table 5) for all contemporary and pre-Hispanic populations suggest the presence of rare alleles at low frequencies or population expansion after a recent bottleneck. (f) The MDS graphs display haplotype differences among all populations and the relationships between the pre-Hispanic Mayas in this study and the contemporary populations from Asia, Beringia, and North and South America based on HVS-I mtDNA sequence data. (g) Identification of the rare haplogroup Clbl4 in the Mexican Maya pre-Hispanic population and low frequency of this haplogroup in the contemporary populations may be due to genetic drift. (h) The sharing of mitochondrial haplotypes and haplogroups among pre-Hispanic individuals also indicated regional gene flow among the pre-Hispanic populations and regional interaction.

In conclusion, the haplotype diversity observed in the pre-Hispanic and contemporary populations of Maya indicates groups that have undergone drift and lineal extinction, with periodic increases in genetic diversity through admixture with adjacent populations.

\section{ACKNOWLEDGMENTS}

We are grateful to anonymous reviewers for their constructive comments, which greatly improved the manuscript. The project was supported by a grant from CONACYTPNPC-2013-2014, CONACYT (sabbatical year), and the Office of the President of Universidad Autónoma Metropolitana.

Received 9 November 2015; revision accepted for publication 3June 2016.

\section{LITERATURE CITED}

Achilli, A., U. A. Perego, C. M. Bravi et al. 2008. The phylogeny of the four pan-American mtDNA haplogroups: Implications for evolutionary and disease studies. PLoS One 3:el764.

Adler, C. J., W. Haak, D. Donlon et al. 2011. The Genographic Consortium: Survival and recovery of DNA from ancient teeth and bones. J. Archaeol. Sci. 38:956-964.

Alves-Silva, J., M. da Silva-Santos, P. E. Guimarães et al. 2000. The ancestry of Brazilian mtDNA lineages. Am.J. Hum. Genet. 67:444-461.
Anderson, S., A. T. Bankier, B. G. Barrell et al. 1981. Sequence and organization of the human mitochondrial genome. Nature 290:457-465.

Andrews, A. P. 2006. Some historic notes and observations on Isla Cancún Quintana Roo, http://research. famsi.org/aztlan/uploads/papers/Andrews-CancunAztlan-06-2.pdf, accessed 19 August 2016.

Andrews, R. M., I. Kubacka, P. F. Chinnery et al. 1999. Reanalysis and revision of the Cambridge Reference Sequence for human mitochondrial DNA. Nat. Genet. 23:147.

Aubry, B. S. 2009. Population structure and interregional interaction in prehispanic Mesoamerica: A biodistance study. Ph.D. diss., Ohio State University.

Arnaiz-Villena, A., G. Vargas-Alarcón, J. Granados et al. 2000. HLA genes in Mexican Mazatecans, the peopling of the Americas and the uniqueness of Amerindians. Tissue Antigens 56:405-416.

Bandelt, H. J., P. Forster, and A. Röhl. 1999. Median-joining networks for inferring intraspecific phylogenies. Mol. Biol. Evol. 16:37-48.

Bandelt, H. J., C. Herrnstadt, Y. G. Yao et al. 2003 Identification of Native American founder mtDNAs through the analysis of complete mtDNA sequences Some caveats. Ann. Hum. Genet. 67:512-524.

Benson, E. P., ed. 1967. Dumbarton Oaks Conference on the Olmec (October 28 and 29), Dumbarton Oaks Research Library and Collection, http://www.doaks.org/ resources/publications/doaks-online-publications/ dumbarton-oaks-conference-on-the-olmec/olmec.pdf.

Bert, F., A. Corella, M. Gené et al. 2004. Mitochondrial DNA diversity in the Llanos de Moxos: Moxo, Movima, and Yuracare Amerindian populations from Bolivia lowlands. Ann. Hum. Biol. 31:9-28.

Bodner, M, U. A. Perego, G. Huber et al. 2012. Rapid coastal spread of first Americans: Novel insights from South America's Southern Cone mitochondrial genomes. Genome Res. 22:811-820.

Boles, T. C., C. C. Snow, and E. Stover. 1995. Forensic DNA testing on skeletal remains from mass graves: A pilot project in Guatemala. J. Forensic Sci. 40:349-355.

Bolnick, D. A., and D. G. Smith. 2003. Unexpected patterns of mitochondrial DNA variation among Native Americans from the southeastern United States. Am. J. Phys Anthropol. 122:336-354.

Bonilla, C., B. Bertoni, S. González et al. 2004. Substantial Native American female contribution to the population of Tacuarembó, Uruguay, reveals past episodes of sexbiased gene flow. Am. J. Hum. Biol. 16:289-297.

Campbell, L., and T. Kaufman. 1985. Mayan linguistics: 
Where are we now? Annu. Rev. Anthropol. 14:187-198.

Campos, P. F., O. E. Craig, G. Turner-Walker et al. 2012. DNA in ancient bone: Where is it located and how should we extract it? Ann. Anat. 194:7-16.

Cann, R. L., M. Stoneking, and A. C. Wilson. 1987. Mitochondrial DNA and human evolution. Nature 325:31-36.

Carlyle, S. W., R. L. Parr, M. G. Hayes et al. 2000. Context of maternal lineages in the Greater Southwest. Am.J. Phys. Anthropol. 113:85-101.

Casas-Vargas, A., A. Gómez, I. Briceño et al. 2011. High genetic diversity on a sample of pre-Columbian bone remains from Guane territories in northwestern Colombia. Am. J. Phys. Anthropol. 146:637-649.

Chen, X. Y., S. Y. Zhao, Y. Wang et al. 2015. A novel mitochondrial DNA deletion in a patient with Pearson syndrome and neonatal diabetes mellitus provides insight into disease etiology, severity, and progression. Mitochondr. DNA 27:1-4.

Crawford, M. H., and K. G. Beaty. 2013. DNA fingerprinting in anthropological genetics: Past, present, future. Invest. Genet. 4:23.

Crawford, M. H., R. C. Rubicz, and M. Zlojutro. 2010. Origins of Aleuts and the genetic structure of populations of the archipelago: Molecular and archaeological perspectives. Hum. Biol. 82:695-717.

Cucina, A., T. D. Price, and E. Magaña-Peralta. 2015. Crossing the peninsula: The role of Noh Bec, Yucatán, in ancient Maya Classic period population dynamics from an analysis of dental morphology and Sr isotopes. Am. J. Hum. Biol. 27:767-778.

da Fonseca, R. R., B. D. Smith, N. Wales et al. 2015. The origin and evolution of maize in the southwestern United States. Nature Plants 1:15007.

Delgado-Sánchez, R., A. Zárate-Moysen, A. Monsalvo-Reyes et al. 2007. Mitochondrial encephalomyopathy, lactic acidosis and stroke-like episodes (MELAS) with the A3243G mutation of the tRNALeu(UUR) gene of mtDNA in native American haplogroup B2. Rev. Neurol. $44: 18-22$.

Derbeneva, O. A., R. Sukernik, N. V. Volodko et al. 2002. Analysis of mitochondrial DNA diversity in the Aleuts of the commander islands and its implications for the genetic history of Beringia. Am. J. Hum. Genet. 71:415-421.

Derenko, M. V., T. Grzybowski, B. A. Malyarchuk et al. 2003. Diversity of mitochondrial DNA lineages in South Siberia. Ann. Hum. Genet. 67(pt 5):391-411.

Derenko, M. V., B. A. Malyarchuk, I. K. Dambueva et al. 2000. Mitochondrial DNA variation in two South Siberian Aboriginal populations: Implications for the genetic history of North Asia. Hum. Biol. 72:945-973.

Derenko, M., B. Malyarchuk, T. Grzybowski et al. 2010. Origin and post-glacial dispersal of mitochondrial DNA haplogroups C and D in northern Asia. PLoS One 5:el5214.

de Saint Pierre, M., C. M. Bravi, J. M. Motti et al. 2012. An alternative model for the early peopling of southern South America revealed by analyses of three mitochondrial DNA. PLoS One 7:e43486.

Dornelles, C. L., J. Battilana, N. J. Fagundes et al. 2004. Mitochondrial DNA and Alu insertions in a genetically peculiar population: The Ayoreo Indians of Bolivia and Paraguay. Am. J. Hum. Biol. 16:479-488.

Dornelles, C. L., S. L. Bonatto, L. B. De Freitas et al. 2005 Is haplogroup $\mathrm{X}$ present in extant South American Indians? Am. J. Phys. Anthropol. 127:439-448.

Elwess, N. L., M. Kopp, E. Lavioe et al. 2015. Analysis of ancient mitochondrial DNA within the Tipu Maya Collection. InternetJ. Biol. Anthropol. 8(1). http://ispub. com/IJBA/8/1/30723.

Excoffier, L., and H. E. Lischer. 2010. Arlequin suite ver 3.5: A new series of programs to perform population genetics analyses under Linux and Windows. Mol. Ecol. Resour. 10:564-567.

Falk, M. J., L. Shen, M. Gonzalez et al. 2015. Mitochondrial Disease Sequence Data Resource (MSeqDR): A global grass-roots consortium to facilitate deposition, curation, annotation, and integrated analysis of genomic data for the mitochondrial disease clinical and research communities. Mol. Genet. Metab. 114:388-396.

Flores-Gutiérrez, D. 2007. Aspectos astronómicos del inframundo en Bonampak, http://132.248.9.9/libroe_2007/0931807_5/12_c08.pdf, accessed 18 August 2016.

Forster, P., R. Harding, A. Torroni et al. 1996. Origin and evolution of Native American mtDNA variation: A reappraisal. Am. J. Hum. Genet. 59:935-945.

Fuselli, S., E. Tarazona-Santos, I. Dupanloup et al. 2003 Mitochondrial DNA diversity in South America and the genetic history of Andean highlanders. Mol. Biol. Evol. 20:1,682-1,691.

Gabriel, M. N., E. F. Huffine, J. H. Ryan et al. 2001. Improved MtDNA sequence analysis of forensic remains using a "mini-primer set" amplification strategy. J. Forensic Sci. 46:247-253.

García-Bour, J., A. Pérez-Pérez, and S. Alvarez. 2004. Early population differentiation in extinct aborigines from Tierra del Fuego-Patagonia: Ancient mtDNA sequences and Y-chromosome STR characterization. Am. J. Phys. Anthropol. 123:361-370.

Goebel, T., M. R. Waters, and D. H. O'Rourke. 2008. The 
late Pleistocene dispersal of modern humans in the Americas. Science 319:1,497-1,502.

Gómez-Carballa, A., L. Catelli, J. Pardo-Seco et al. 2015. The complete mitogenome of a 500-year-old Inca child mummy. Sci. Rep. 5:16462.

González-Martín, A., A. Gorostiza, L. Regalado-Liu et al. 2015. Demographic history of indigenous populations in Mesoamerica based on mtDNA sequence data. PLoS One 10:e0131791.

González-Oliver, A., L. Márquez-Morfín, J. C. Jiménez et al. 2001. Founding Amerindian mitochondrial DNA lineages in ancient Maya from Xcaret, Quintana Roo. Am. J. Phys. Anthropol. 116:230-235.

Gorostiza, A., V. Acunha-Alonzo, L. Regalado-Liu et al. 2012. Reconstructing the history of Mesoamerican populations through the study of the mitochondrial DNA control region. PLoS One 7:e44666.

Green, L. D., J. N. Derr, and A. Knight. 2000. mtDNA affinities of the peoples of North-Central Mexico. Am. J. Hum. Genet. 66:989-998.

Grobman, A., D. Bonavia, T. D. Dillehay et al. 2012. Preceramic maize from Paredones and Huaca Prieta, Peru. Proc. Natl. Acad. Sci. USA 109:1,755-1,759.

Houston, S., J. Robertson, and D. Stuart. 2000. The language of classic Maya inscriptions. Curr. Anthropol. 41:321-356.

Hughes, S., T. J. Hayden, C. J. Douady et al. 2006. Molecular phylogeny of the extinct giant deer, Megaloceros giganteus. Mol. Phylogenet. Evol. 40:285-291.

Ingman, M., and U. Gyllensten. 2007. Rate variation between mitochondrial domains and adaptive evolution in humans. Hum. Mol. Genet. 16:2,281-2,287.

Ingman, M., H. Kaessmann, S. Pääbo et al. 2000. Mitochondrial genome variation and the origin of modern humans. Nature 408:708-713.

Inomata, T., J. MacLellan, D. Triadan et al. 2015. Development of sedentary communities in the Maya lowlands: Coexisting mobile groups and public ceremonies at Ceibal, Guatemala. Proc. Natl. Acad. Sci. USA 112:4,268-4,273.

Inomata, T., D. Triadan, K. Aoyama et al. 2013. Early ceremonial constructions at Ceibal, Guatemala, and the origins of lowland Maya civilization. Science 340:467-471.

Just, R. S., T. M. Diegoli, J. L. Saunier et al. 2008. Complete mitochondrial genome sequences for 265 African American and US "Hispanic" individuals. Forensic Sci. Int. Genet. 2:e45-e48.

Kemp, B. M., A. González-Oliver, R. S. Malhi et al. 2010. Evaluating the farming/language dispersal hypothesis with genetic variation exhibited by populations in the Southwest and Mesoamerica. Proc. Natl. Acad. Sci. USA
107:6,759-6,764.

Kemp, B. M., A. Resendez, J. Berrelleza et al. 2005. An analysis of ancient Aztec mtDNA from Tlatelolco: PreColumbian relations and the spread of Uto-Aztecan. In Biomolecular Archaeology: Genetic Approaches to the Past, D. M. Reed, ed. Carbondale: Center for Archaeological Investigations, Southern Illinois University, 22-46.

Kemp, B. M., and T. G. Schurr. 2010. Ancient and modern genetic variation in the Americas. In Human Variation in the Americas: Human Variation in the Americas, M. B. Auerbach, ed. Carbondale: Center for Archaeological Investigations, Southern Illinois University, 12-50.

Keyser-Tracqui, C., E. Crubézy, and B. Ludes. 2003. Nuclear and mitochondrial DNA analysis of a 2,000-year-old necropolis in the Egyin Gol Valley of Mongolia. Am. J. Hum. Genet. 73:247-260.

Kohler, T. A., and K. M. Reese. 2014. Long and spatially variable Neolithic Demographic Transition in the North American Southwest. Proc. Natl. Acad. Sci. USA 111:10,101-10,106.

Kolman, C. J., and E. Bermingham. 1997. Mitochondrial and nuclear DNA diversity in the Chocó and Chibcha Amerinds of Panamá. Genetics 147:1,289-1,302.

Kong, Q. P., Y. G. Yao, C. Sun et al. 2003. Phylogeny of east Asian mitochondrial DNA lineages inferred from complete sequences. Am. J. Hum. Genet. 73:671-676.

Kumar, S., C. Bellis, M. Zlojutro et al. 2011. Large scale mitochondrial sequencing in Mexican Americans suggests a reappraisal of Native American origins. BMC Evol. Biol. 11:293.

Kunz, M. L., and R. E. Reanier. 1994. Paleoindians in Beringia: Evidence from arctic Alaska. Science 263:660-662.

Lalueza, C., A. Pérez-Pérez, E. Prats et al. 1997. Lack of founding Amerindian mitochondrial DNA lineages in extinct aborigines from Tierra del Fuego-Patagonia. Hum. Mol. Genet. 6:41-46.

Lalueza-Fox, C., M. T. Gilbert, A. J. Martínez-Fuentes et al. 2003. Mitochondrial DNA from pre-Columbian Ciboneys from Cuba and the prehistoric colonization of the Caribbean. Am. J. Phys. Anthropol. 121:97-108.

Law, D. 2013. Mayan historical linguistics in a New Age. Lang. Linguist. Compass 7:141-156.

LeBlanc, S. A., L. S. C. Kreisman, B. M. Kemp et al. 2007. Quids and aprons: Ancient DNA from artifacts from the American Southwest. J. Field Archeol. 32:161-176.

Lewis, C. M., Jr., B. Lizárraga, R. Y. Tito et al. 2007. Mitochondrial DNA and the peopling of South America. Hum. Biol. 79:159-178.

Malhi, R. S., J. S. Cybulski, R. Y. Tito et al. 2010. Brief communication: Mitochondrial haplotype C4c confirmed 
as a founding genome in the Americas. Am. J. Phys. Anthropol. 141:494-497.

Malhi, R. S., H. M. Mortensen, J. A. Eshleman et al. 2003. Native American mtDNA prehistory in the American Southwest. Am. J. Phys. Anthropol. 120:108-124.

Maniatis, T., E. F. Fritsch, and J. Sambrook. 1989. Molecular Cloning. Cold Spring Harbor, NY: Cold Spring Harbor Laboratory Press.

Melton, P. E., N. F. Baldi, R. Barrantes et al. 2013. Microevolution, migration, and the population structure of five Amerindian populations from Nicaragua and Costa Rica. Am. J. Hum. Biol. 25:480-490.

Melton, P. E., I. Briceño, A. Gómez et al. 2007. Biological relationship between Central and South American Chibchan speaking populations: Evidence from mtDNA. Am. J. Phys. Anthropol. 133:753-770.

Mendisco, F., C. Keyser, V. Seldes et al. 2014. Genetic diversity of a late prehispanic group of the Quebrada de Humahuaca, northwestern Argentina. Ann. Hum. Genet. 78:367-380.

Merrill, W. L., R. J. Hard, J. B. Mabry et al. 2009. The diffusion of maize to the southwestern United States and its impact. Proc. Natl. Acad. Sci. USA 106:21,019-21,026.

Merriwether, D. A., D. M. Reed, and R. E. Ferrell. 1997. Ancient and contemporary mitochondrial DNA variation in the Maya. In Bones of the Maya: Studies of Ancient Skeletons, S. L. Whittington and D. M. Reed, eds. Washington, DC: Smithsonian Institute Press, 208-217.

Meyer, S., G. Weiss, and A. von Haeseler. 1999. Pattern of nucleotide substitution and rate heterogeneity in the hypervariable regions I and II of human mtDNA. Genetics 152:1,103-1,110.

Mishmar, D., E. Ruiz-Pesini, P. Golik et al. 2003. Natural selection shaped regional mtDNA variation in humans. Proc. Natl. Acad. Sci. USA 100:171-176.

Montiel-Sosa, J. F., M. D. Herrero, M. de L. Muñoz et al. 2013. Phylogenetic analysis of mitochondrial DNA in a patient with Kearns-Sayre syndrome containing a novel 7629-bp deletion. Mitochondr. DNA 24:420-431.

Moraga, M. L., P. Rocco, J. F. Miquel et al. 2000. Mitochondrial DNA polymorphisms in Chilean aboriginal populations: Implications for the peopling of the southern cone of the continent. Am. J. Phys. Anthropol. 113:19-29.

Moraga, M., C. M. Santoro, V. G. Standen et al. 2005. Microevolution in prehistoric Andean populations: Chronologic mtDNA variation in the desert valleys of northern Chile. Am.J. Phys. Anthropol. 127:170-181.

Muñoz, M. de L., M. Lopez-Armenta, M. Moreno-Galeana et al. 2012a. Extraction and electrophoresis of DNA from the remains of Mexican ancient populations. In $\mathrm{Gel}$
Electrophoresis_-Part 2, Sameh Magdeldin, ed. Rijeka, Croatia: InTech, 470-500.

Muñoz, M. de L., E. Ramos, A. Díaz-Badillo et al. 2012b. Migration of pre-Hispanic and contemporary human Mexican populations. In Causes and Consequences of Human Migration: An Evolutionary Perspective, M. H. Crawford and B. C. Campbell, eds. Cambridge: Cambridge University Press, 417-435.

Nei, M. 1987. Molecular Evolutionary Genetics. New York: Columbia University Press.

Nesheva, D. 2014. Aspects of ancient mitochondrial DNA analysis in different populations for understanding human evolution. Balk.J. Med. Gen. 17:5-14.

Ochoa, L. 2004. Comalcalco ancient city of brick and stucco. Voices of Mexico 69:95-99. http://www.revistascisan. unam.mx/Voices/pdfs/6918.pdf.

Pakendorf, B., and M. Stoneking. 2005. Mitochondrial DNA and human evolution. Annu. Rev. Genomics Hum. Genet. 6:165-183.

Peñaloza-Espinosa, R. I., D. Arenas-Aranda, R. M. CerdaFlores et al. 2007. Characterization of mtDNA haplogroups in 14 Mexican indigenous populations. Hum. Biol. 79:313-320.

Perego, U. A., A. Achilli, N. Angerhofer et al. 2009. Distinctive Paleo-Indian migration routes from Beringia marked by two rare mtDNA haplogroups. Curr. Biol. 19:1-8.

Perego, U. A., N. Angerhofer, M. Pala et al. 2010. The initial peopling of the Americas: A growing number of founding mitochondrial genomes from Beringia. Genome Res. 20:1,174-1,179.

Piperno, D. R., A. J. Ranere, I. Holst et al. 2009. Starch grain and phytolith evidence for early ninth millennium B.P. maize from the Central Balsas River Valley, Mexico. Proc. Natl. Acad. Sci. USA 106:5,019-5,024.

Pohl, M. E., D. R. Piperno, K. O. Pope et al. 2007. Microfossil evidence for pre-Columbian maize dispersals in the neotropics from San Andres, Tabasco, Mexico. Proc. Natl. Acad. Sci. USA 104:6,870-6,875.

Pringle, H. 2013. Archaeology: Deep dig shows Maya architecture arose independently of Olmec's. Science 340:417.

Raff, J. A., D. A. Bolnick, J. Tackney et al. 2011. Ancient DNA perspectives on American colonization and population history. Am. J. Phys. Anthropol. 146:503-514.

Raghavan, M., M. Steinrücken, K. Harris et al. 2015. Population genetics: Genomic evidence for the Pleistocene and recent population history of Native Americans. Science 349:aab3884.

Ragsdale, C. S., and H. J. Edgar. 2015. Cultural interaction and biological distance in Postclassic period Mexico. 
Am. J. Phys. Anthropol. 157:121-133.

Ranere, A. J., D. R. Piperno, I. Holst et al. 2009. The cultural and chronological context of early Holocene maize and squash domestication in the Central Balsas River Valley, Mexico. Proc. Natl. Acad. Sci. USA 106:5,014-5,018.

Rieux, A., A. Eriksson, M. Li et al. 2014. Improved calibration of the human mitochondrial clock using ancient genomes. Mol. Biol. Evol. 31:2,780-2,792.

Rubicz, R., T. G. Schurr, P. L. Babb et al. 2003. Mitochondrial DNA variation and the origins of the Aleuts. Hum. Biol. 75:809-835.

Rust, W. F., and R. J. Sharer. 1988. Olmec settlement data from La Venta, Tabasco, Mexico. Science 242:102-104.

Salas, A., J. Lovo-Gómez, V. Alvarez-Iglesias et al. 2009. Mitochondrial echoes of first settlement and genetic continuity in El Salvador. PLoS One 4:e6882.

Sandoval, K., L. Buentello-Malo, R. Peñaloza-Espinosa et al. 2009. Linguistic and maternal genetic diversity are not correlated in Native Mexicans. Hum. Genet. 126:521-531

Santos, M., R. H. Ward, and R. Barrantes. 1994. mtDNA variation in the Chibcha Amerindian Huetar from Costa Rica. Hum. Biol. 66:963-77.

Santos, S. E., A. K. Ribeiro-Dos-Santos, D. Meyer et al. 1996. Multiple founder haplotypes of mitochondrial DNA in Amerindians revealed by RFLP and sequencing. Ann Hum. Genet. 60:305-319.

Scheibye-Knudsen, M., K. Scheibye-Alsing, C. Canugovi et al. 2013. A novel diagnostic tool reveals mitochondrial pathology in human diseases and aging. Aging (Albany, NY) 5:192-208.

Schele, E. D. 2012. The untold story of Alberto Ruz and his archaeological excavations at Palenque, México: A micro- and macrohistorical approach. Ph.D. diss. University of Texas at Austin.

Scherer, A. K. 2007. Population structure of the Classic period Maya. Am. J. Phys. Anthropol. 132:367-380.

Shokolenko, I. N., and M. F. Alexeyev. 2015. Mitochondrial DNA: A disposable genome? Biochim. Biophys. Acta 1,852:1,805-1,809.

Smith, S., M. G. Hayes, G. Cabana et al. 2009. Inferring population continuity versus replacement with aDNA: A cautionary tale from the Aleutian Islands. Hum. Biol. 81:19-38.

Soares, P., L. Ermini, N. Thomson et al. 2009. Correcting for purifying selection: An improved human mitochondrial molecular clock. Am. J. Hum. Genet. 84:740-759.

Söchtig, J., V. Álvarez-Iglesias, A. Mosquera-Miguel et al. 2015. Genomic insights on the ethno-history of the Maya and the "Ladinos" from Guatemala. BMC Genom ics 16:131.
Snow, M. H., K. R. Durand, and D. G. Smith. 2010. Ancestra Puebloan mtDNA in context of the greater Southwest. J. Archaeol. Sci. 37:1,635-1,645.

Starikovskaya, E. B., R. I. Sukernik, O. A. Derbeneva et al. 2005. Mitochondrial DNA diversity in indigenous populations of the southern extent of Siberia, and the origins of Native American haplogroups. Ann. Hum. Genet. 69:67-89.

Starikovskaya, Y. B., R. I. Sukernik, T. G. Schurr et al. 1998 mtDNA diversity in Chukchi and Siberian Eskimos: Implications for the genetic history of ancient Beringia and the peopling of the New World. Am.J. Hum. Genet. 63:1,473-1,491.

Tajima, F. 1983. Evolutionary relationship of DNA sequences in finite populations. Genetics 105:437-460.

Tamm, E., T. Kivisild, M. Reidla et al. 2007. Beringian standstill and spread of Native American founders. PLoS One 2:e829.

Tamura, K. 2000. On the estimation of the rate of nucleotide substitution for the control region of human mitochondrial DNA. Gene 259:189-197.

Tamura, K., G. Stecher, D. Peterson et al. 2013. MEGA6: Molecular Evolutionary Genetics Analysis version 6.0. Mol. Biol. Evol. 30:2,725-2,729.

Theyab, J. B., S. Al-Bustan, and M. H. Crawford. 2012. The genetic structure of the Kuwaiti population: mtDNA inter- and intra-population variation. Hum. Biol. 84:379-403.

Torroni, A., Y. S. Chen, O. Semino et al. 1994. mtDNA and Ychromosome polymorphisms in four Native American populations from southern Mexico. Am.J. Hum. Genet. 54:303-318.

Torroni, A., T. G. Schurr, M. F. Cabell et al. 1993. Asian affinities and continental radiation of the four founding Native American mtDNAs. Am. J. Hum. Genet. 53:563-590.

Vona, G., A. Falchi, P. Moral et al. 2005. Mitochondria sequence variation in the Guahibo Amerindian population from Venezuela. Am. J. Phys. Anthropol. 127:361-369.

Wallace, D. C., M. D. Brown, and M. T. Lott. 1999. Mitochondrial DNA variation in human evolution and disease. Gene 238:211-230.

Ward, R. H., F. M. Salzano, S. L. Bonatto et al. 1996. Mitochondrial DNA polymorphism in three Brazilian Indian tribes. Am. J. Hum. Biol. 8:317-323.

Williams, S. R., N. A. Chagnon, and R. S. Spielman. 2002 Nuclear and mitochondrial genetic variation in the Yanomamö: A test case for ancient DNA studies of prehistoric populations. Am. J. Phys. Anthropol. 117:246-259. 
Wilson, M. R., J. A. DiZinno, D. Polanskey et al. 1995a. Validation of mitochondrial DNA sequencing for forensic casework analysis. Int. J. Legal Med. 108:68-74.

Wilson, M. R., D. Polanskey, J. Butler et al. 1995b. Extraction,

PCR amplification and sequencing of mitochondrial
DNA from human hair shafts. Biotechniques 18:662-669. Yunis, J. J., and E. J. Yunis. 2013. Mitochondrial DNA (mtDNA) haplogroups in 1526 unrelated individuals from 11 departments of Colombia. Genet. Mol. Biol. 36:329-335.

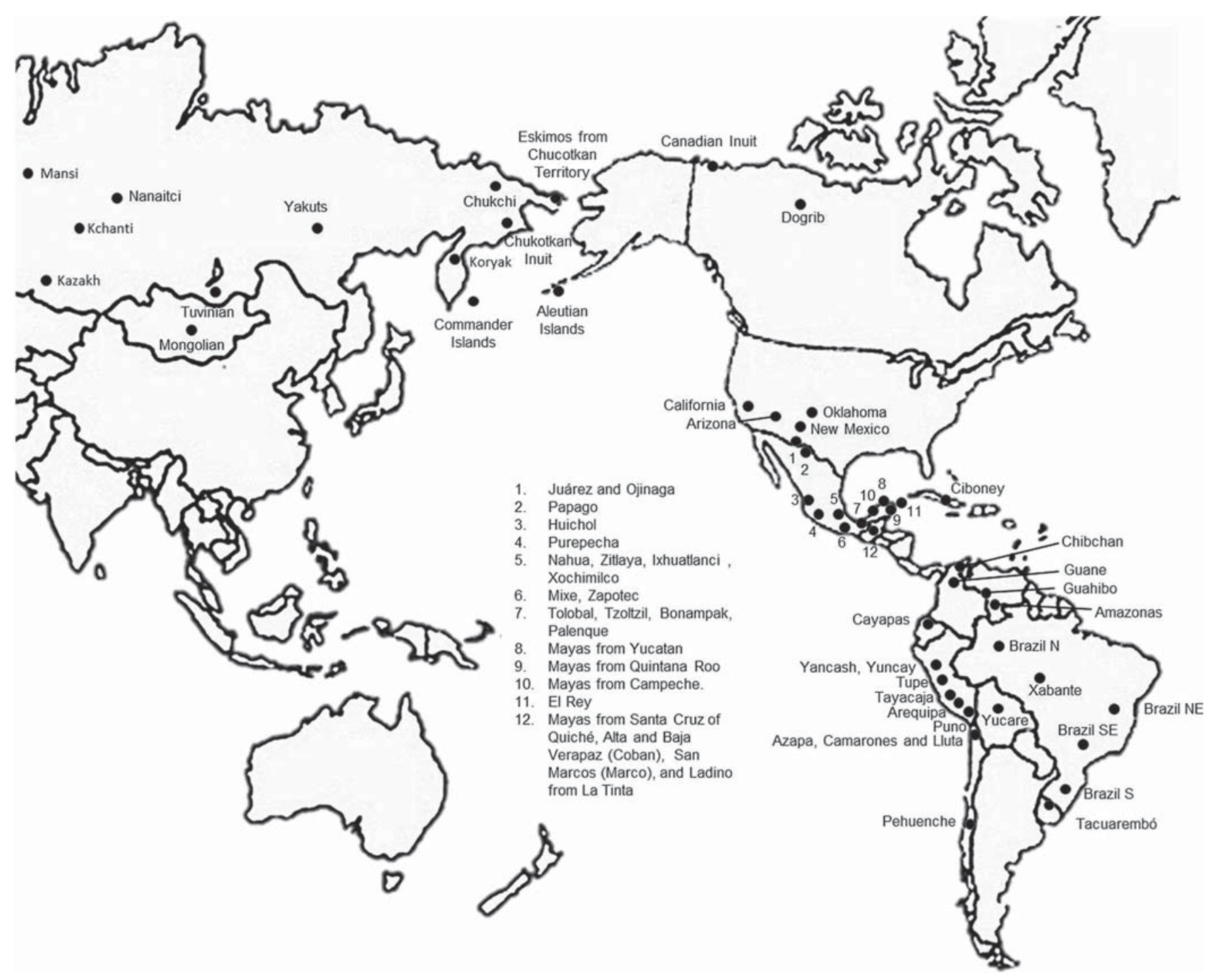

SUPPLEMENTARY FIGURE S1. Geographic locations of the sequences analyzed in this study: locations of all samples from ancient and contemporary individuals described in Table 1 and Supplementary Table S1.

SUPPLementARY TABLE S1. Please visit the following web address to view Supplementary Table S1: http://digitalcommons .wayne.edu/cgi/viewcontent.cgi?filename=21\&article=2574\&context=humbiol\&type=additional. 


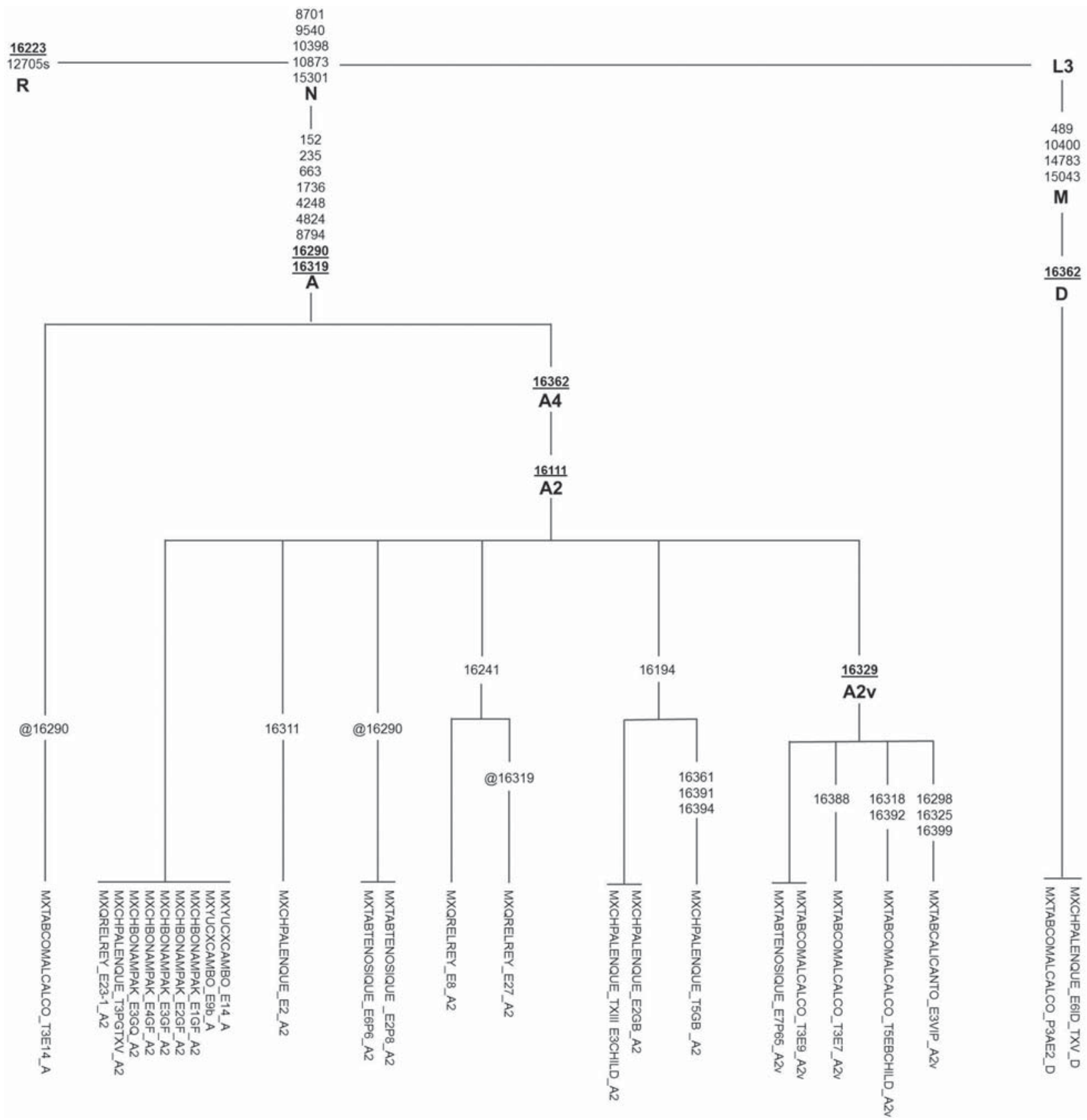

SUPPLEMENTARY FIGURE S2A. mtDNA phylogenetic tree of the pre-Hispanic haplogroups A and D. The figure shows the phylogenetic reconstruction of 25 HVS-I mtDNA sequences belonging to the pre-Hispanic Maya haplogroup clades. 


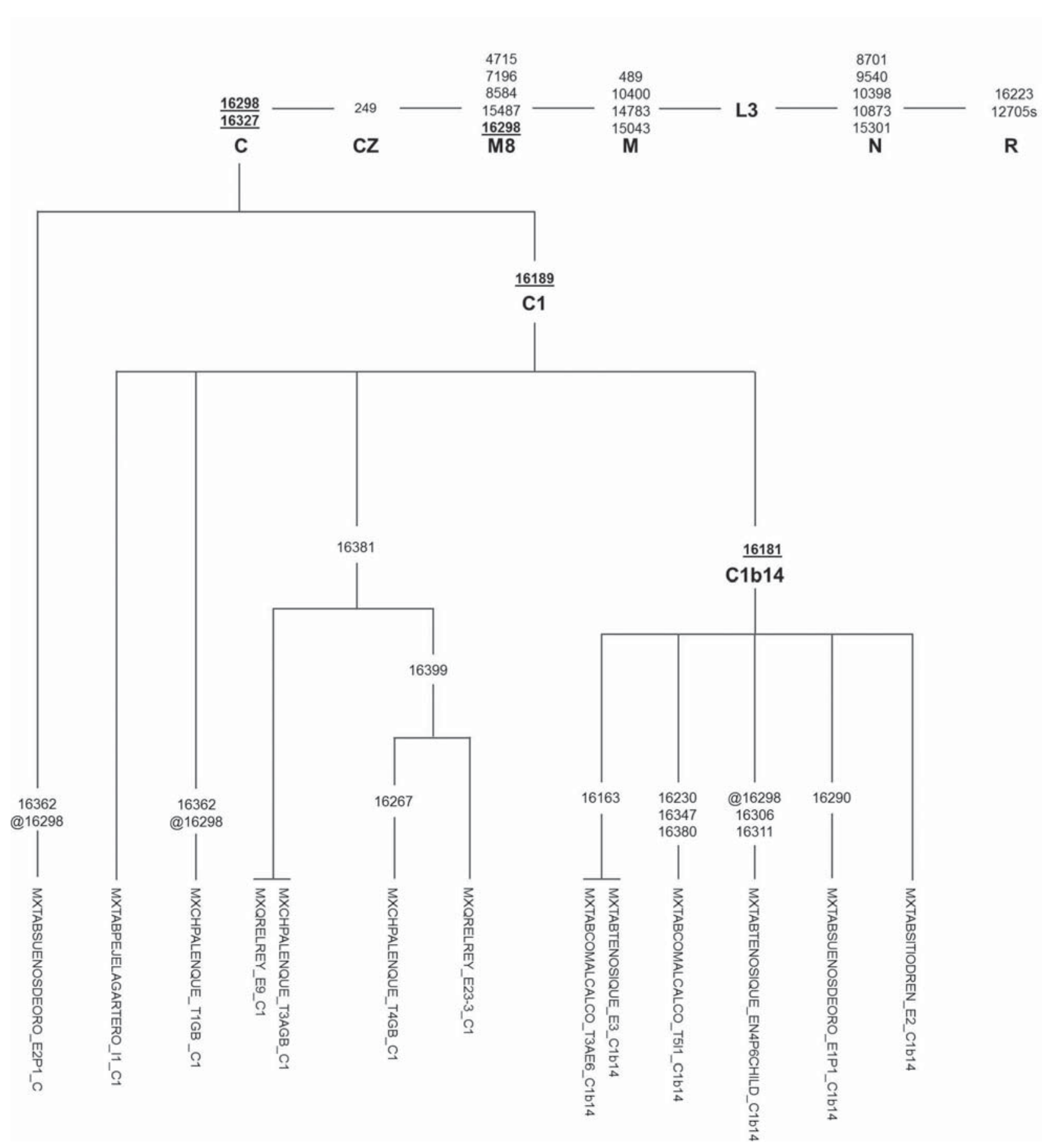

SUPPLEMENTARY FIGURE S2B. mtDNA phylogenetic tree of the pre-Hispanic haplogroup $C$. The figure shows the phylogenetic reconstruction of 13 HVS-I mtDNA sequences belonging to the pre-Hispanic Maya haplogroup clades. 


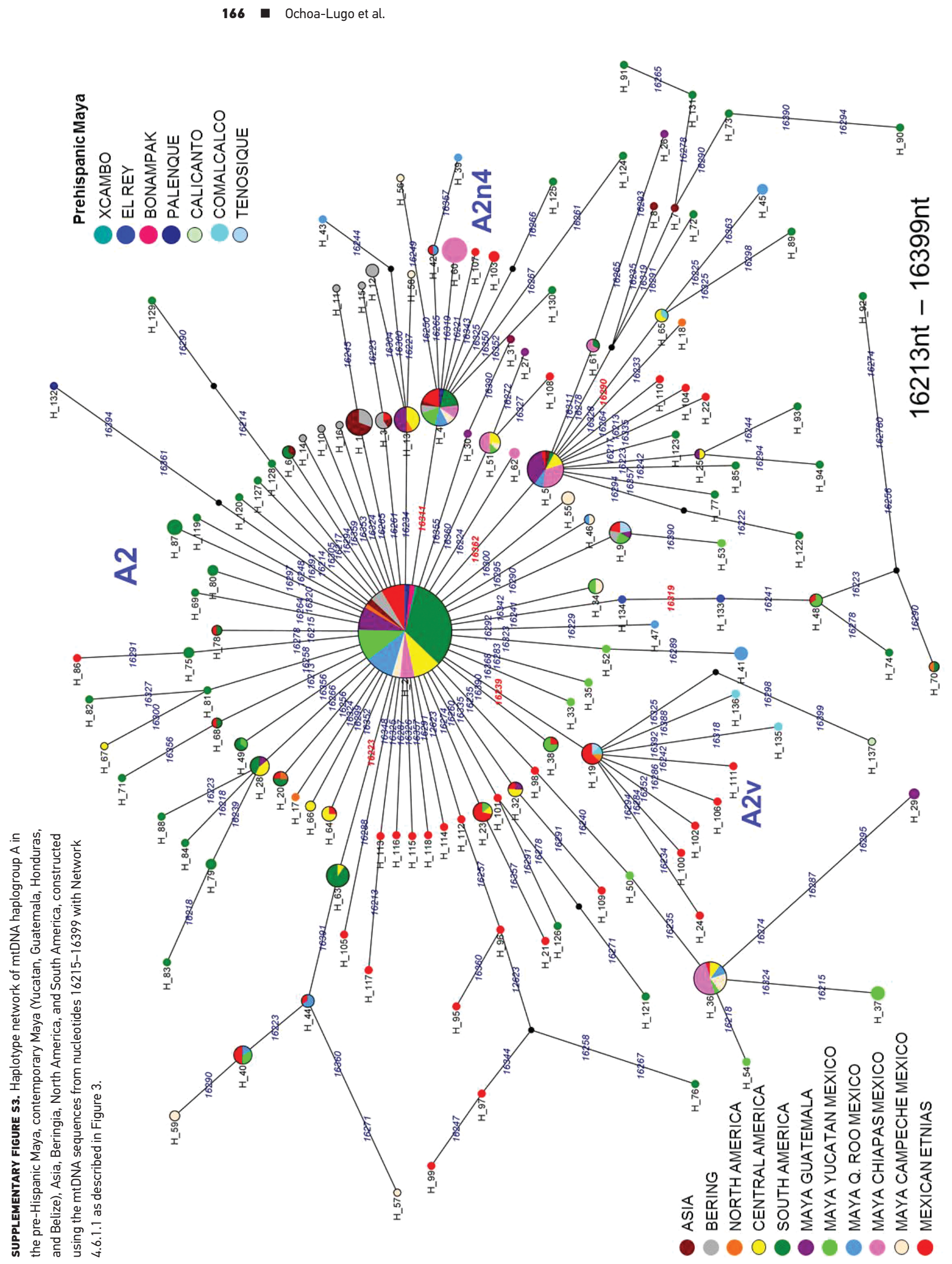




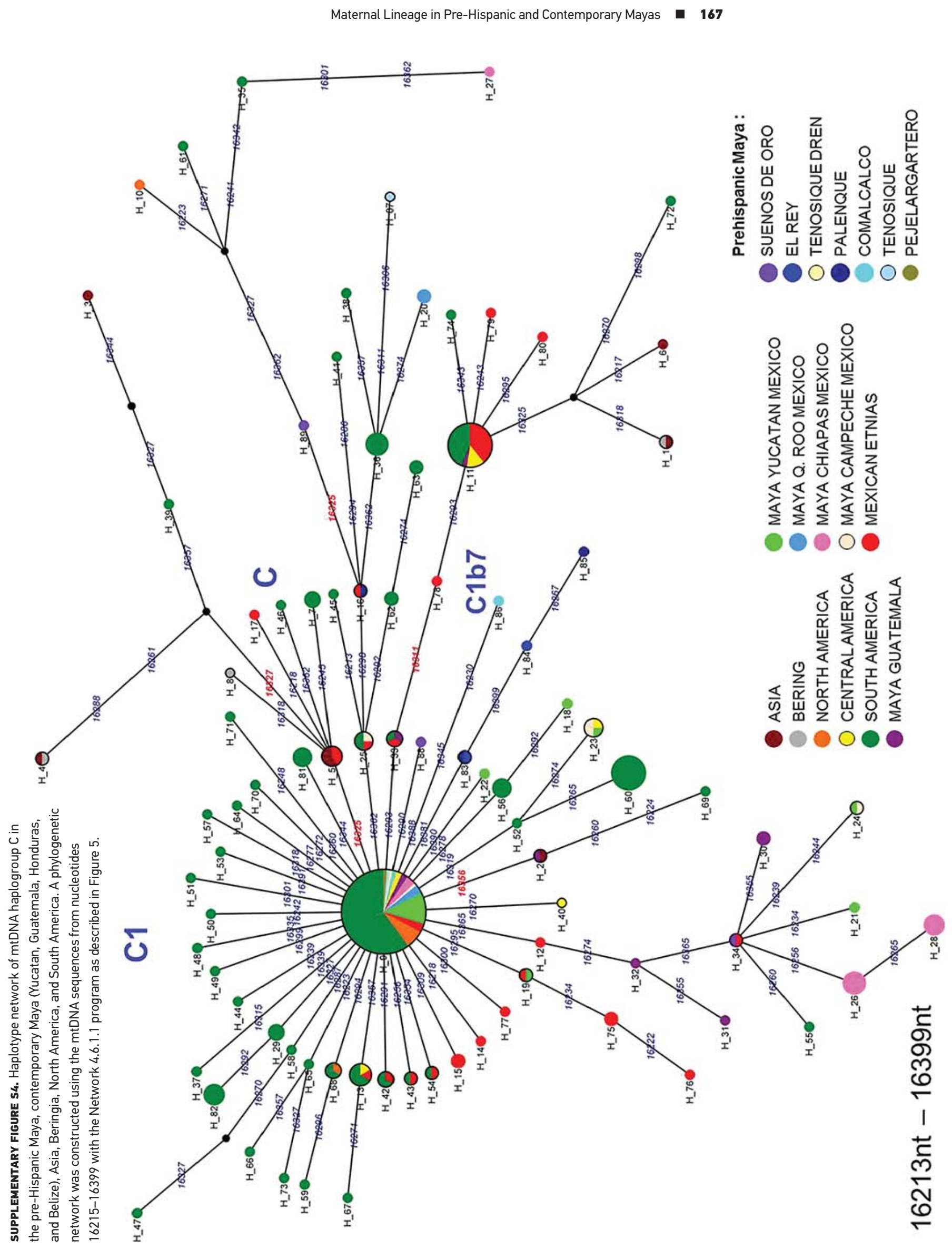


Copyright of Human Biology is the property of Wayne State University Press and its content may not be copied or emailed to multiple sites or posted to a listserv without the copyright

holder's express written permission. However, users may print, download, or email articles for individual use. 